DIGITAL MODEL OF THE BATES CREEK ALLUVIAL AQUIFER

NEAR CASPER, WYOMING

by Kent C. Glover

U.S. GEOLOGICAL SURVEY

Water-Resources Investigations Report 82-4068

Prepared in cooperation with the

WYOMING STATE ENGINEER

Cheyenne, Wyoming

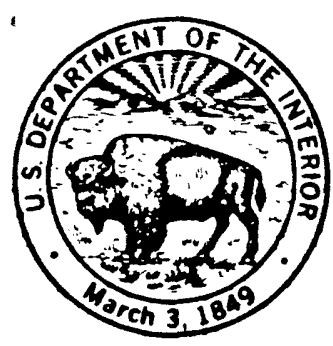


UNITED STATES DEPARTMENT OF THE INTERIOR

JAMES G. WATT, Secretary

GEOLOGICAL SURVEY

Dallas L. Peck, Director

For additional information write to:

District Chief

U.S. Geological Survey

2120 Capitol Avenue

P.0. Box 1125

Cheyenne, Wyoming 82003
Copies of this report can be purchased from:

Open-File Services Section Western Distribution Branch U.S. Geological Survey Box 25425, Federal Center Lakewood, Colorado 80225 (Telephone: [303] 234-5888) 
Abstract-0 1

Introduction- 1

Purpose and scope-1 3

Previous investigations- 3

Geology of the study area- 3

Hydrologic properties of the Bates Creek alluvial aquifer-a..... 3

Potentiometric surface-1 8

Saturated thickness

Hydraulic conductivity- 8

Specific yield-_a 12

Recharge and discharge-1

Stream-aquifer relationships-_. 13

Underflow-.... 13

Precipitation-15

Irrigation recharge-17

Evapotranspiration- 17

Pumpage-- 22

Simulation mode1- 22

Flow equations-... 24

Numerical methods-.- 25

Application of the simulation model

Steady-state model development- 27

Transient model development- 31

Predictive analysis-a 36

Summary and conclusions-1 44

References cited-_. 45

\section{ILLUSTRATIONS}

Figures 1-6. Maps showing

1. Location of study area-n 2

2. Geology, water-level data, and depth to Cretaceous rocks in the Bates Creek alluvial valley-n 4

3. Base of the Bates Creek alluvial aquifer-...... 6

4. Potentiometric surface of the Bates Creek alluvial aquifer on March 30, 1978-.. 10

5. Irrigated acreage in the Bates Creek alluvial valleym 18

6. Finite-difference grid and boundary conditions used to model the Bates Creek alluvial aquifer-

Figures 7-9. Graphs showing

7. Results of sensitivity analysis with different values of specific yield 33

8. Results of sensitivity analysis with different values of irrigation recharge-1... 33

9. Projected net streamflow depletion-a.... 41 
Table 1. Summary of water-level fluctuations in 25 observation wells during 1977 and 1978-............- 9

2. Streamflow losses and gains along Bates and Corral Creeks on March 31, 1978, and October 17, 1978-......... 14

3. Summary of precipitation recharge analysis for 1978 growing season--...- 16

4. Consumptive uses and irrigation requirement of various vegetation types during the April to October 1978 growing season-a.-. 20

5. Excess applied water to irrigated acreage within the study area--...- 21

6. Estimated maximum rate of evapotranspiration from the Bates Creek aquifer during the April

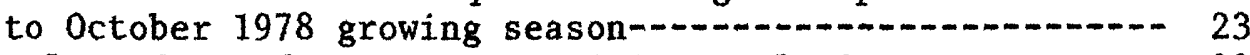

7. Results of steady-state sensitivity analysis-............ 32

8. Difference between calibrated and observed stream leakage on October 18, 1978, at Corral and Bates

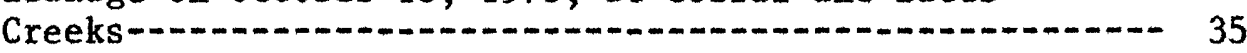

9. Assumed irrigation diversions to be operating during

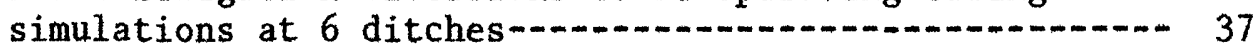

10. Assumed irrigation pumpage for simulation scenarios II and III--...- 38

11. Predicted water-level decline at wells as a result of pumping after 10-year simulations-................ 40

12. Predicted streamflow depletion along various stream reaches at the end of the 1983 irrigation season--.---. 42

13. Predicted streamflow depletion along various stream reaches at the end of the 1988 irrigation season-....... 43 
For those readers interested in using the International System of Units (SI), the following table may be used to convert inch-pound units of measurement used in this report to SI units:

Multiply

acre

acre-foot

foot $(\mathrm{ft})$

square foot $\left(\mathrm{ft}^{2}\right)$

foot per mile $(\mathrm{ft} / \mathrm{mi})$

foot per second $(\mathrm{ft} / \mathrm{s})$

cubic foot per second $\left(\mathrm{ft}^{3} / \mathrm{s}\right)$

foot per day $(\mathrm{ft} / \mathrm{d})$

inch (in.)

mile (mi)

square mile $\left(\mathrm{mi}^{2}\right)$
By

0.4047

$1,233.0$

0.3048

0.0929

0.1894

0.3048

0.02832

0.3048

25.4

1.609

2.590
To obtain

hectare (ha) cubic meter $\left(\mathrm{m}^{3}\right)$

meter (m)

square meter $\left(\mathrm{m}^{2}\right)$

meter per kilometer $(\mathrm{m} / \mathrm{km})$

meter per second $(\mathrm{m} / \mathrm{s})$

cubic meter per second $\left(\mathrm{m}^{3} / \mathrm{s}\right)$

meter per day $(\mathrm{m} / \mathrm{d})$

millimeter $(\mathrm{mm})$

kilometer $(\mathrm{km})$

square kilometer $\left(\mathrm{km}^{2}\right)$

National Geodetic Vertical Datum of 1929 (NGVD of 1929) is a geodetic datum derived from a general adjustment of the first-order level nets of both the United States and Canada, formerly called mean sea level. 


\title{
DIGITAL MODEL OF THE BATES CREEK ALLUVIAL AQUIFER
}

NEAR CASPER, WYOMING

\author{
By Kent C. Glover
}

\begin{abstract}
A digital model was used to simulate ground-water flow within the Bates Creek alluvial aquifer, southwest of Casper, Wyoming. Hydrologic data collected during 1977 and 1978 were used to develop the flow model under steady-state and transient conditions. Three scenarios for operating the stream-aquifer system were evaluated with the digital model. The scenarios represent (1) no ground-water pumping, (2) pumping by all existing wells, and (3) pumping by all existing and proposed wells. The model simulations incorporated average values of stream discharge, ground-water pumpage and water use as input parameters. A decrease in the quantity of ground-water discharge to Bates Creek is predicted to occur through 1988 as a result of pumping. The magnitude and timing of the predicted decrease in ground-water discharge may differ from actual ground-water discharge if hydrologic conditions through 1988 vary significantly from the averaged input values used in the simulations. This is particularly likely to occur if stream discharge entering the model area is insufficient to prevent Bates Creek from flowing in its middle and lower reaches.
\end{abstract}

\section{INTRODUCTION}

Bates Creek, shown in figure 1, has been a center for sheep and cattle ranching since the $1880^{\prime} \mathrm{s}$. Extensive plantings of hay and alfalfa have been irrigated with water diverted from Bates Creek and its tributaries. The flow of Bates Creek has been totally appropriated since early in this century.

A number of irrigation wells have been drilled near the creek to supplement surface-water supplies, and more are planned in the near future. The effect of developing ground-water supplies for irrigation on the surface-water supply of Bates Creek and its tributaries is described in this report. This investigation was made in cooperation with the Wyoming State Engineer. The study area includes approximately 55 square miles in southeast Natrona County. The area is bounded on the west by the North Platte River and on the north and south by relatively impermeable shale of Cretaceous age. The eastern boundary was chosen to be far enough upstream to be outside the influence of present and proposed ground-water development. 


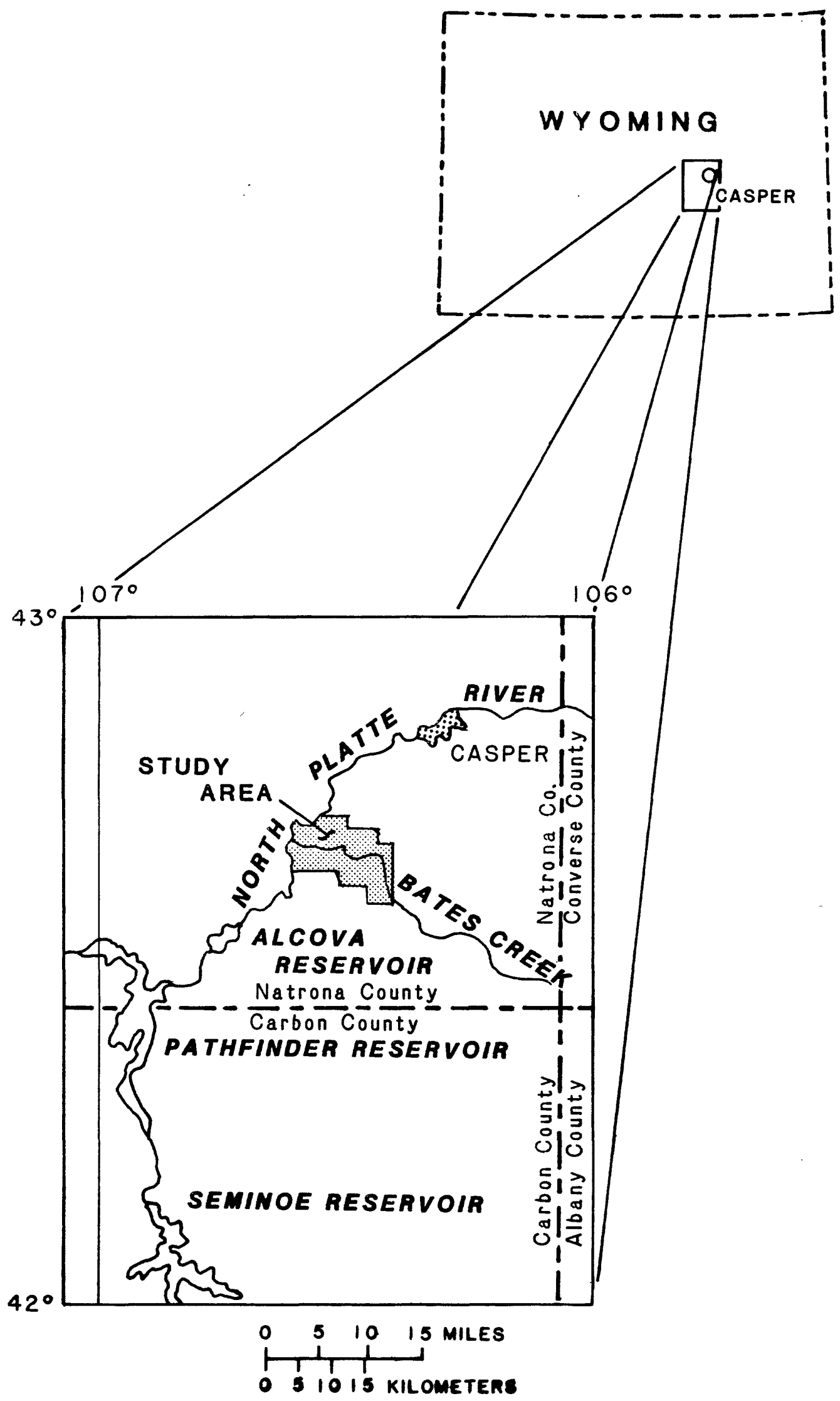

Figure 1.--Location of study area 


\section{Purpose and Scope}

The purpose of this investigation was to describe the interrelationship of Bates Creek and its tributaries with the associated alluvial aquifer. The specific objective of the study was to develop a digital model that mathematically simulates the ground-water-flow system. The model can be used to project the effect of present and proposed groundwater pumping on streamflow and water levels in the aquifer.

\section{Previous Investigations}

Despite the extensive agricultural use of the Bates Creek Valley, few water-resources investigations have been made. As a result, an adequate data base for model development did not exist prior to this study. Two studies that were useful in providing geologic information are Crist and Lowry (1972) and Crist (1974). Streamflow has been measured at three gaging stations within the Bates Creek drainage. The mean streamflow for the June through October low flow period at a U.S. Geo-

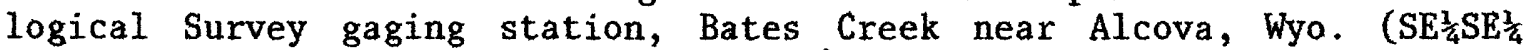
sec. 1, T. 31 N., R. 82 W.) was $7.60 \mathrm{ft}^{3} / \mathrm{s}$. This average is based on the years 1916 through 1924 and 1935 through 1961. The U.S. Soil Conservation Service operated two streamflow-gaging stations from 1974 through 1977 (Reuben Kammerer, written commun., 1978). The mean streamflow from June through October at these two gaging stations was $12.2 \mathrm{ft}^{3} / \mathrm{s}$ at Bates

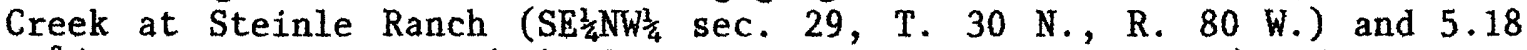

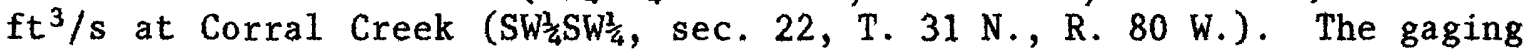
station, Bates Creek at Steinle Ranch, is outside the current study area.

\section{GEOLOGY OF THE STUDY AREA}

The Bates Creek Valley has been incised into relatively impermeable shale of Cretaceous age and is filled with unconsolidated alluvial and windblown deposits of Quaternary age (fig. 2). Thickness of the alluvium, as determined by drilling, ranges from less than 20 feet at several locations to as much as 100 feet in areas where irrigation wells have been developed. Terrace and flood-plain deposits of poorly sorted clastic material range in size from clay to boulders. Test drilling throughout the study area indicated that the alluvium along the North Platte River and Bates Creek contains a large percentage of cobbles and boulders, while alluvium along Stinking Creek generally is made up of finer grained materials. Windblown deposits along the north boundary of the study area consist primarily of fine-grained sand and silt.

\section{HYDROLOGIC PROPERTIES OF THE BATES CREEK ALLUVIAL AQUIFER}

The Bates Creek alluvial aquifer, as used in this report, includes saturated material of Quaternary age along Bates Creek and its tributaries. Alluvium along the North Platte River within the study area and any saturated windblown deposits are also included. Cretaceous shale underlies the aquifer throughout the study area, forming a relatively impermeable base. The configuration of the base of the aquifer is shown in figure 3 . The aquifer is unconfined throughout the study area. 


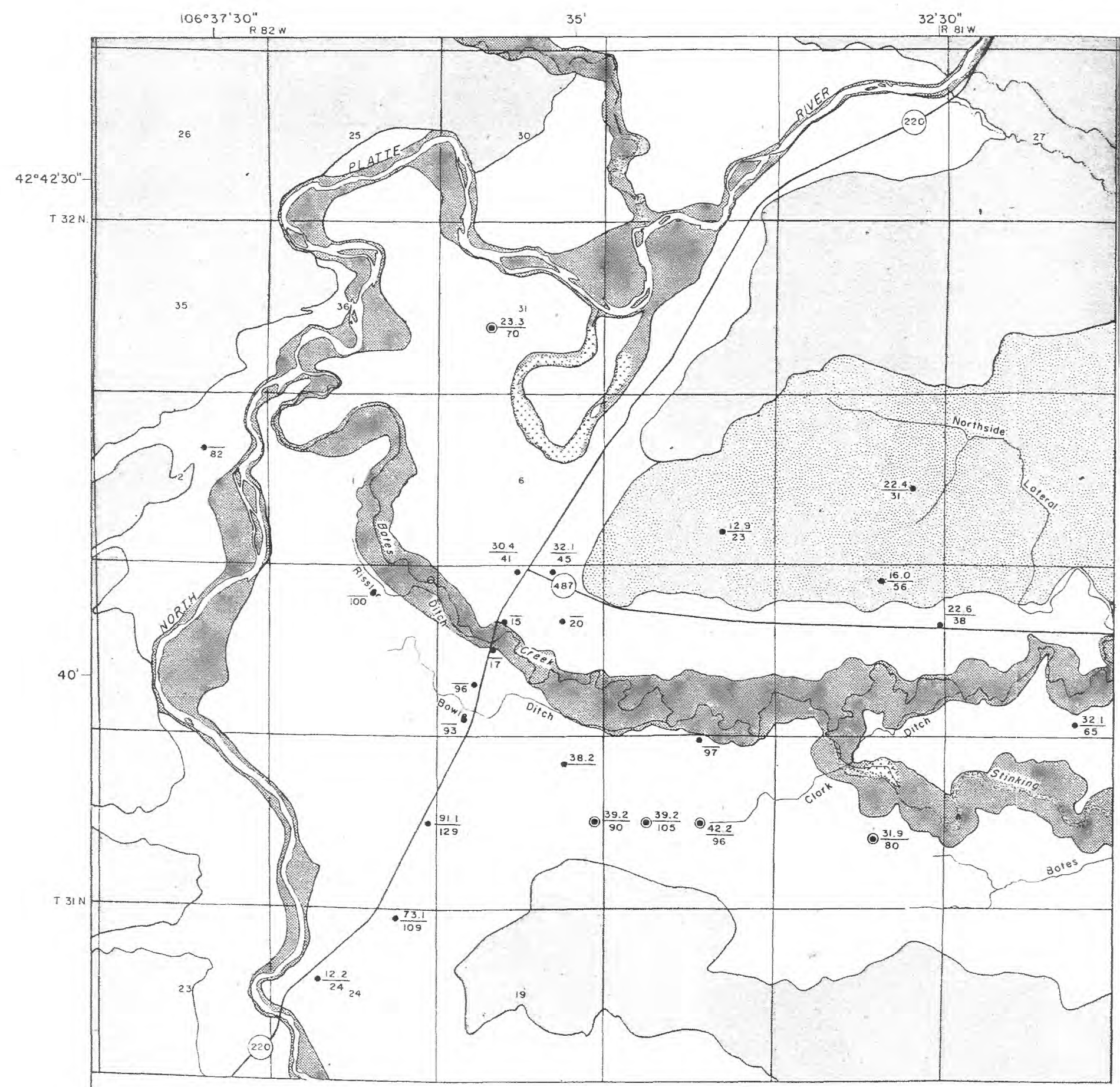

EXPLANATION

$42^{\circ} 37^{\prime} 30^{\prime \prime}$

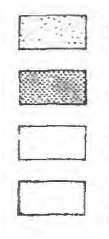

DUNE BAND

FLODD-PLAIN DEPOSITS

TERRACE DEPOEITS

UNDIFFERENTIATED CRETACEOUS ROCKS
- $\frac{392}{90}$ IRRIGATION WELL--Number abovo line is

septh to water below land surface on

March 30. 1978. Number below line is

surface. D for degth to water indicates

that no water is ootained from alluvium:

blank indicates either septh ta water or

depth to badrock was not neasured

$\frac{12.2}{24}$ DOMESTIC. STOCK OR TEST WELL

- test well used to estimate vertical STREAMBED HYDRAULIC CONDUCTIVITY $106^{\circ} 37^{\prime} 30^{\prime \prime \prime} 82$

Base from J.S. Geologica! Survey AIgova SE,

Bessemer Wountain. Freeland. and Twin

Buttas qua 0 -rangles. $1: 24,000$

Figure 2.--Geology, water-level data, and depth to Cretaceous rocks in the Bates Creek alluvial valley. 


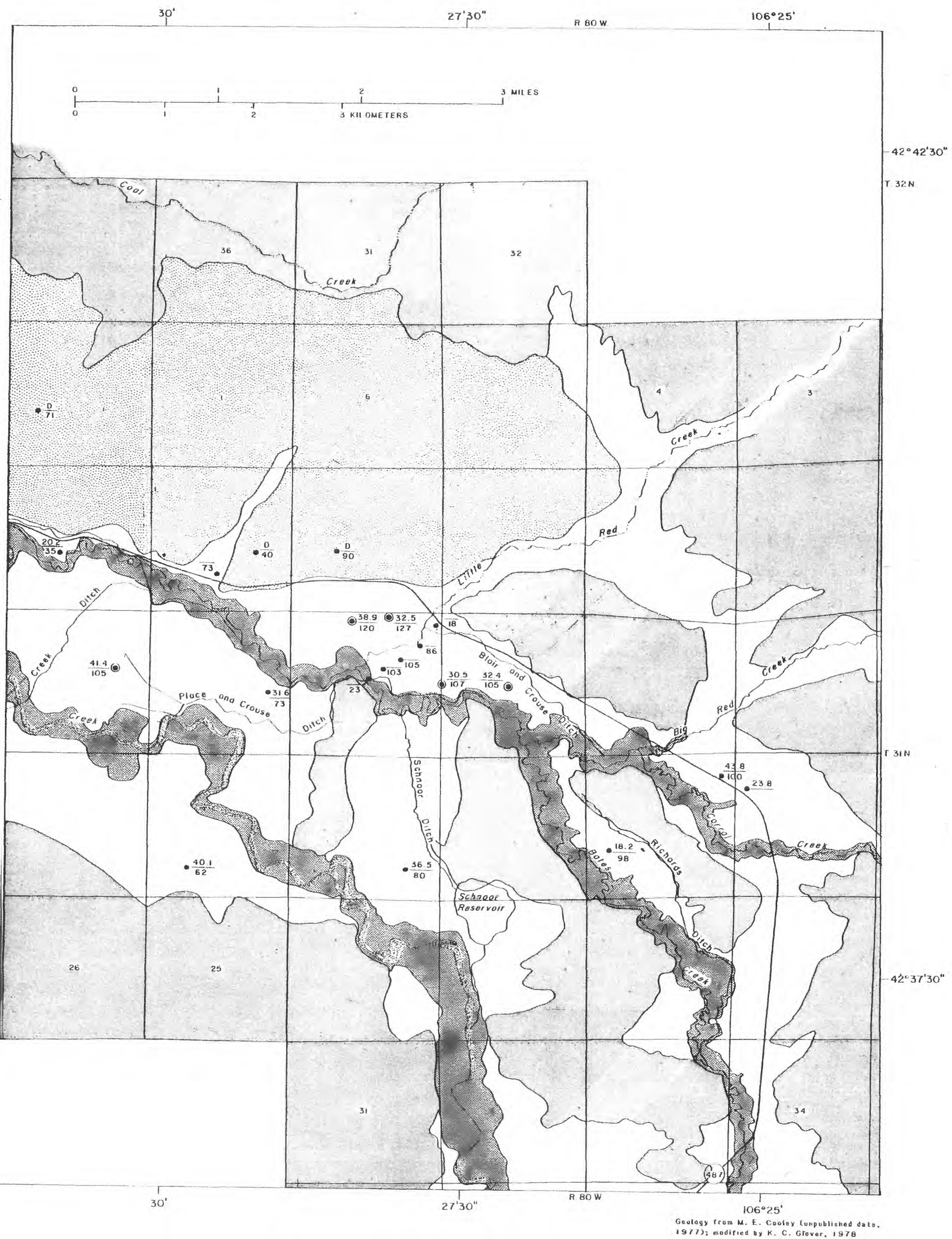




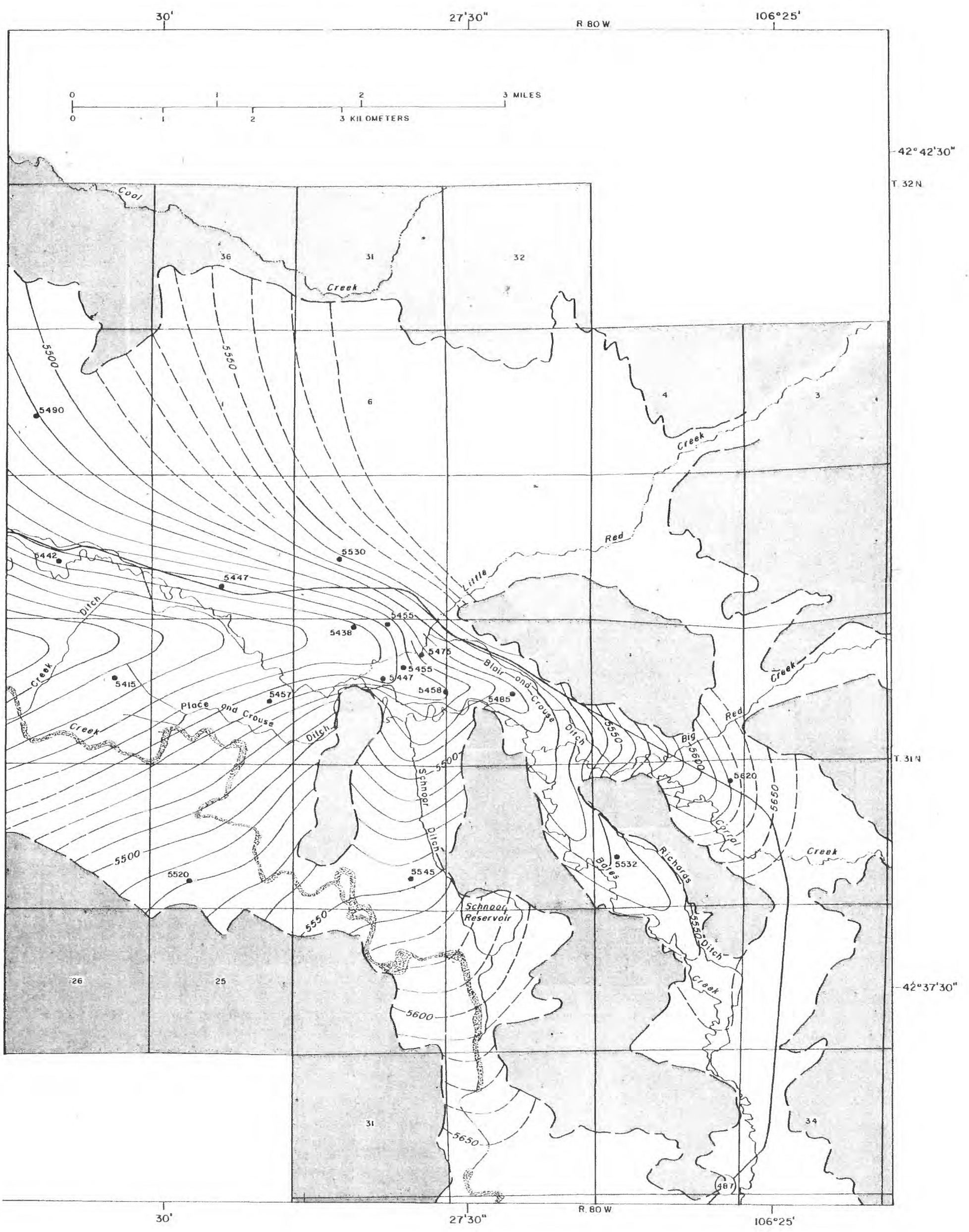




\section{Potentiometric Surface}

If the altitudes of water-levels in wells tapping an aquifer with virtually horizontal flow are plotted on a map and contoured, the result is called a potentiometric surface. The direction of ground-water flow in most aquifers is perpendicular to the potentiometric contours. Wells used for water-level measurements in this study are screened in most of the saturated thickness of the aquifer; therefore, small vertical components of ground-water flow are neglected. In this report, the water table is equated with the potentiometric surface.

The potentiometric surface of the alluvial aquifer on March 30 , 1978 , is shown in figure 4. Water-level measurements made during the period December 15, 1977, to March 30, 1978, indicate that the potentiometric surface shown in figure 4 approximates steady-state conditions.

Ground-water levels change in response to changes in the rates of ground-water recharge and discharge. A network of 25 observation wells was measured monthly from December 1977 through October 1978 to monitor water-level changes within the study area. A summary of these measurements is presented in table 1 for three periods of record corresponding to the winter low-flow period, the spring high-flow period, and the summer irrigation period. The significant rise in water levels during April and May occurs in response to an increase in recharge from precipitation and surface-water irrigation. The water-level decline from May 22,1977 , to October 18, 1978, was caused primarily by ground-water pumpage and by decreased rates of recharge from precipitation and irrigation. Changes in aquifer recharge and discharge are discussed more fully in a later section of this report.

\section{Saturated Thickness}

The saturated thickness of the Bates Creek alluvial aquifer within the study area is calculated as the difference between the potentiometric surface shown in figure 4 and the aquifer base shown in figure 3 . A saturated thickness of less than 20 feet occurs in the area north of Wyoming Highway 487 and east of Wyoming Highway 220. Saturated alluvium is 20 to 40 feet thick along Stinking Creek and 45 to 80 feet thick along Bates Creek.

\section{Hydraulic Conductivity}

Hydraulic conductivity is a measure of the ability of an aquifer to transmit water and is defined as the volume of water transmitted per unit time through a unit cross-sectional area under a unit hydraulic gradient. Hydraulic conductivity generally is a function of three-dimensional location within an aquifer; however, in a two-dimensional approximation, it is assumed as the vertically averaged value. Hydraulic conductivity can have directional properties, but, because these properties of the alluvium are not known within the study area, the aquifer is assumed to be isotropic. 


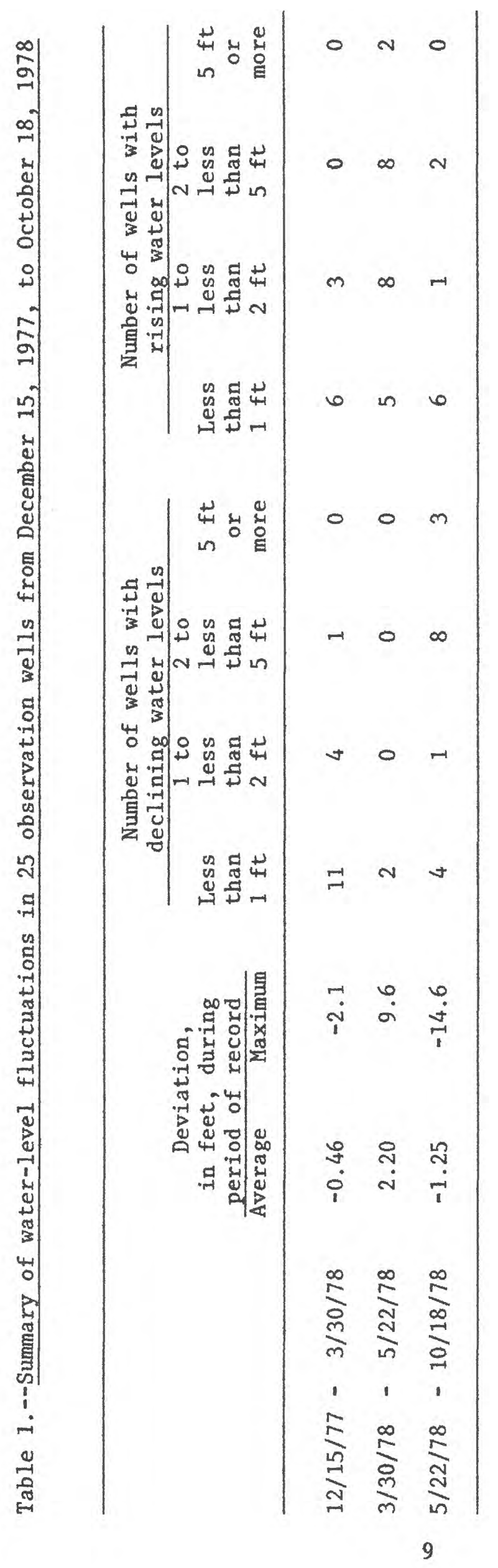




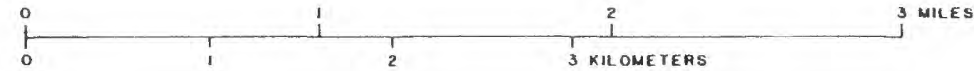

\section{- 5}

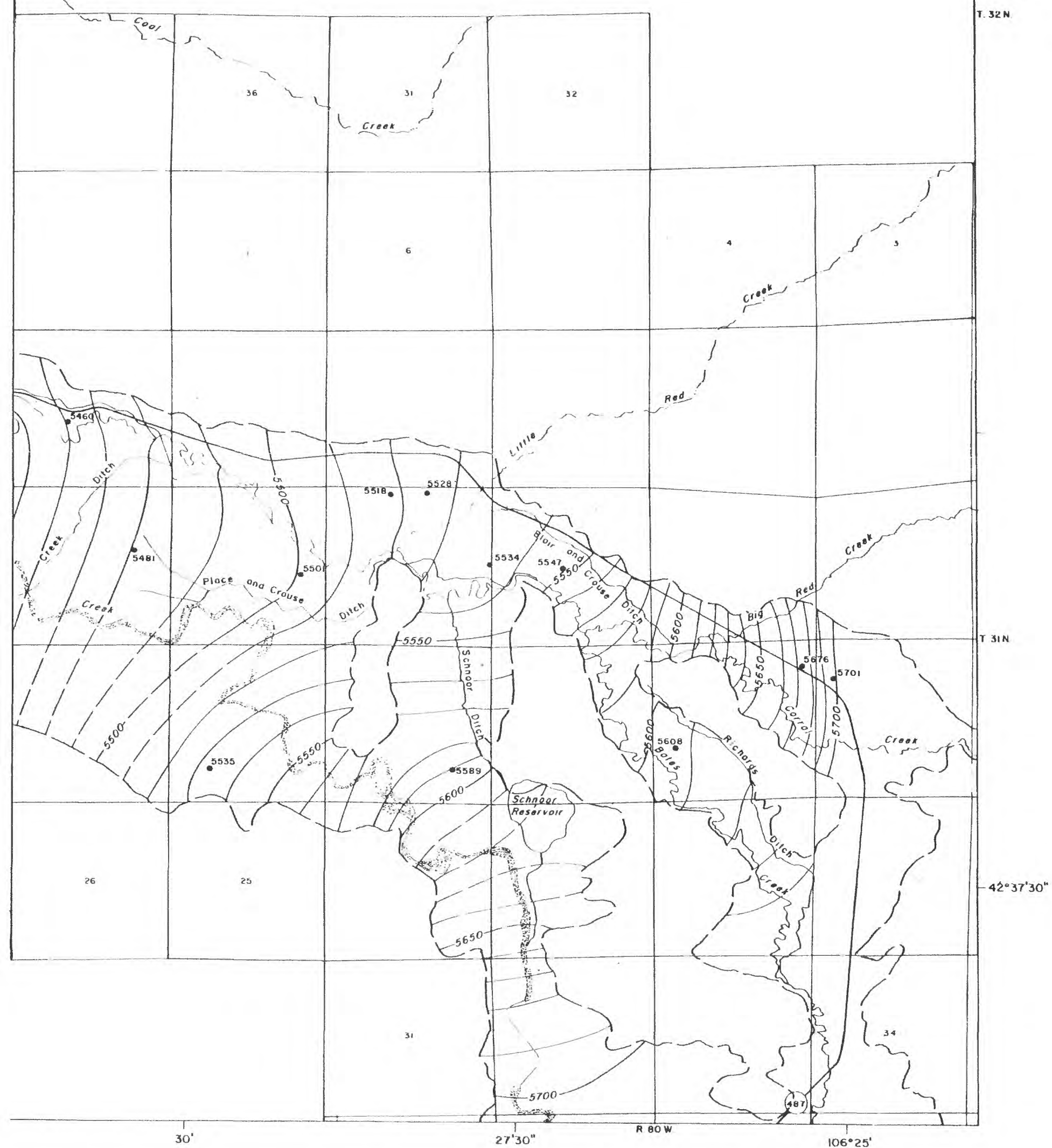


Two commonly used methods of estimating hydraulic conductivity are aquifer tests and estimates from drillers logs. Aquifer tests were not performed as a part of this study, but Crist (1975) reported values of $100 \mathrm{ft} / \mathrm{d}$ to $1,160 \mathrm{ft} / \mathrm{d}$ for alluvium from aquifer tests along the North Platte River in Wyoming. The procedure used in this study was to assign values of hydraulic conductivity to verbal descriptions of samples from 22 U.S. Geological Survey test holes within the study area. A vertically averaged hydraulic conductivity was determined for each test hole location by using the following equation:

$$
\hat{\mathrm{K}}=\frac{\sum_{i=1}^{n} k_{i} b_{i}}{\sum_{i=1}^{n} b_{i}}
$$

where $\hat{\mathrm{K}}$ = vertically averaged hydraulic conductivity, in feet per day,

$\mathrm{K}_{\mathrm{i}}=$ hydraulic conductivity of the sampled interval, in feet per day,

$b_{i}=$ thickness of the sampled interval, in feet, and

$\mathrm{n}$ = number of intervals sampled.

Values of $K_{i}$ are from Lohman (1972, p. 53). The vertically averaged hydraulic conductivities were estimated to range from $190 \mathrm{ft} / \mathrm{d}$ to 900 $\mathrm{ft} / \mathrm{d}$.

\section{Specific Yield}

Specific yield is defined as the volume of water that can be released by gravity drainage from a unit volume of saturated aquifer and is a measure of the amount of water available from storage in an aquifer. Because no information was available on the distribution of specific yield within the study area, a constant value was assumed. Crist (1975) reported a value of 0.23 for the valley-fill aquifer along the North Platte River in Wyoming.

\section{Recharge and Discharge}

The configuration of a potentiometric surface is controlled by aquifer properties such as hydraulic conductivity and by the rate and distribution of aquifer recharge and discharge. The major sources of recharge to the Bates Creek alluvial aquifer are underflow, infiltration from precipitation and surface irrigation, and stream leakage. Major sources of aquifer discharge include ground-water discharge to Bates Creek and the North Platte River, pumping, and evapotranspiration along stream flood plains. 


\section{Stream-Aquifer Relationships}

The Bates Creek alluvial aquifer is in hydraulic continuity with Bates Creek, Corral Creek, and the North Platte River. Discharge measurements made during March 1978 indicated reaches of streamflow loss or gain that were in general agreement with reaches of loss or gain inferred from the potentiometric surface shown in figure 4 . The magnitude of these losses and gains are given in table 2. In general, Corral Creek lost water while Bates Creek gained. Measurements of streamflow gain by the North Platte River within the study area during February and March 1978 ranged from 9.5 to $10.7 \mathrm{ft}^{3} / \mathrm{s}$ indicating that the river was a major area of aquifer discharge.

Stinking Creek flows intermittently in response to snowmelt or rainfall. Discharge measurements during April 1978 indicated that Stinking Creek, when flowing, lost water at a rate of $1.2 \mathrm{ft}^{3} / \mathrm{s}$ per mile of stream length. The potentiometric-surface map of the Bates Creek aquifer (fig. 4) shows Stinking Creek as being perched.

Streamflow measurements made on October 17, 1978, indicated a stream-aquifer relationship that varied only slightly from results obtained in March 1978. The results of the October measurements are given in table 2. No measurements were made from May 1978 through September 1978 when surface-water diversions and ground-water pumping occurred. Therefore, no definite conclusions can be made concerning changes in stream-aquifer relations during the 1978 irrigation season.

Vertical streambed hydraulic conductivity was estimated at two locations shown in figure 2. Water-level measurements in wells installed in the streambed indicated head differences between Bates Creek and the underlying aquifer of $1.42 \mathrm{ft}$ at the site in sec. 11, T. $31 \mathrm{~N}$., R. 81 W., and $0.76 \mathrm{ft}$ at the site in sec, 12, T. $31 \mathrm{~N} ., \mathrm{R} .82 \mathrm{~W}$. Discharge measurements were made upstream and downstream from both locations. Darcy's law was applied to these data by assuming a streambed thickness of $1 \mathrm{ft}$ and an average stream width of $10 \mathrm{ft}$. The resulting estimates of streambed hydraulic conductivity at the two well sites are $1.65 \times 10^{-5} \mathrm{ft} / \mathrm{s}$ and $2.43 \times 10^{-5} \mathrm{ft} / \mathrm{s}$. These estimates are in general agreement with the value of $3.0 \times 10^{-5} \mathrm{ft} / \mathrm{s}$ given by Moore and Jenkins (1966) for the Arkansas River Valley in Colorado.

\section{Underflow}

Water recharges the aquifer in the study area as underflow across the upstream boundaries along Stinking, Bates, and Corral Creeks. The rates of underflow could not be measured directly. However, hydraulic gradients and transmissivity values obtained during development of the digital model indicate recharge rates by underflow of $2.67 \mathrm{ft}^{3} / \mathrm{s}$ along Corral Creek, $2.77 \mathrm{ft}^{3} / \mathrm{s}$ along Bates Creek, and $5.41 \mathrm{ft}^{3} / \mathrm{s}$ along Stinking Creek. 
Table 2.--Streamflow losses and gains along Bates and Corral Creeks on March 31,1978 , and October 17, 1978

\begin{tabular}{|c|c|c|c|}
\hline \multirow[b]{2}{*}{ Stream reach } & \multicolumn{3}{|c|}{$\begin{array}{l}\text { Streamflow loss }(-) \text { or gain }(+) \text {, in } \\
\text { cubic feet per second }\end{array}$} \\
\hline & March & 31,1978 & October 17,1978 \\
\hline $\begin{array}{l}\text { Corral Creek from Wyoming Highway } 487 \\
\text { to mouth }\end{array}$ & & -1.8 & -2.0 \\
\hline $\begin{array}{l}\text { Bates Creek from Richards Ditch to Place } \\
\text { and Crouse Ditch }\end{array}$ & & +.9 & +1.8 \\
\hline $\begin{array}{l}\text { Bates Creek from Place and Crouse Ditch } \\
\text { to Clark Ditch }\end{array}$ & & +.8 & +.6 \\
\hline $\begin{array}{l}\text { Bates Creek from Bates Creek Ditch to } \\
\text { Clark Ditch }\end{array}$ & & +1.6 & +1.5 \\
\hline $\begin{array}{l}\text { Bates Creek from Clark Ditch to one-half } \\
\text { mile below Stinking Creek }\end{array}$ & & +2.9 & +2.8 \\
\hline $\begin{array}{c}\text { Bates Creek from one-half mile below Stin } \\
\text { Creek to Wyoming Highway } 220\end{array}$ & king & +1.8 & +2.1 \\
\hline Bates Creek from Wyoming Highway 220 to $\mathrm{m}$ & louth & -2.7 & -2.1 \\
\hline
\end{tabular}


Potentiometric contours shown in figure 4 suggest inflow of water to the aquifer system along the northern boundary of the study area. The high infiltration and percolation rates of the sand dunes along this boundary produce an area having virtually no runoff. Test drilling during the study suggested that only a small part of the area of the sand dunes overlies saturated material. A recharge rate of $2.86 \mathrm{ft}^{3} / \mathrm{s}$ distributed along the aquifer boundry was required to maintain the potentiometric surface during model development.

\section{Precipitation}

Only part of the precipitation percolates to most aquifers. The remainder is lost to evaporation, plant consumptive use, surface runoff, and changes in soil-moisture storage. Recharge estimates during the winter months are complicated further by drifting and sublimation of snow.

Recharge by precipitation to the Bates Creek alluvium during the period December 15, 1977, to March 30, 1978, was estimated using criteria modified from Lappala (1978, p. 95). Soil infiltration was assumed to have occurred only during days when precipitation fell and the average daily temperature was greater than $27^{\circ} \mathrm{F}$. Precipitation that occurred when the air temperature was less than $27^{\circ} \mathrm{F}$ was assumed to be lost to drifting and sublimation. These criteria were applied to data from the

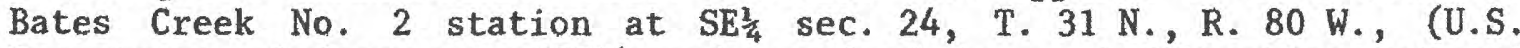
Department of Commerce, 1978) and resulted in an infiltration rate of 0.44 inch per month.

Part of the water that infiltrates the soil surface is held in the unsaturated zone by surface tension. Percolation to the saturated zone generally will occur in soils with a fairly high soil-moisture content. No mapping of soil-moisture conditions was attempted during this study. Instead, the percolation of water to the saturated zone from December 1977 to March 1978 was assumed to have occurred only on acreage that was irrigated during late November 1977. This acreage lies primarily north of Wyoming Highway 487. Ground-water recharge in these areas from December 15, 1977, to March 30, 1978, was estimated as the amount of infiltration water. Recharge in other areas was assumed to be zero during this period.

An approach described by Trelease and others (1970) was used to estimate precipitation recharge during the 1978 growing season. A summary of this precipitation analysis for 1978 is given in table 3. The total precipitation from April 1978 through October 1978 was 12.19 in. The long term precipitation from April through October is 9.07 in. Effective precipitation is defined as the part of total monthly precipitation that is effective in meeting consumptive-use requirements of vegetation. Excess precipitation was computed as the difference between total monthly precipitation and effective precipitation. The excess precipitation becomes surface runoff, ground-water recharge, and soilmoisture storage. Development of the digital model indicated that 80 percent of excess applied water entered the aquifer as recharge. 
Table 3.--Summary of precipitation recharge analyses for the 1978 growing season

\begin{tabular}{|c|c|c|c|}
\hline & $\begin{array}{l}\text { Total } \\
\text { precipitation } \\
\text { (inches) }\end{array}$ & $\begin{array}{l}\text { Effective } \\
\text { precipitation } \\
\text { (inches) }\end{array}$ & $\begin{array}{c}\text { Excess } \\
\text { precipitation } \\
\text { (inches) }\end{array}$ \\
\hline April & 2.70 & 2.40 & 0.30 \\
\hline Maym-n-m-n & 6.41 & 4.10 & 2.31 \\
\hline 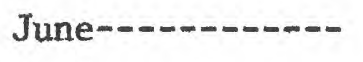 & .75 & .70 & .05 \\
\hline July & 1.10 & 1.05 & .05 \\
\hline August-- & 1.13 & 1.05 & .08 \\
\hline September--..-- & .03 & .03 & .00 \\
\hline October $-\cdots$ & .07 & .07 & .00 \\
\hline
\end{tabular}




\section{Irrigation Recharge}

Seepage from surface-water irrigation is a major source of groundwater recharge. Irrigated acreage within the study area is shown in figure 5. The amount of seepage is dependent on the amount of water applied to the field, the consumptive use requirements of the crop, soil moisture, and soil permeability. In this study, consumptive use was estimated with the Blaney-Criddle method (Trealease and others, 1970) and compared to measured stream diversions. The Blaney-Criddle equation for monthly consumptive use is

$$
u=k\left(\frac{t p}{100}\right)
$$

where $u=$ monthly consumptive use, in inches;

$k=$ monthly consumptive-use coefficient;

$t=$ mean monthly temperature, in ${ }^{\circ} \mathrm{F}$; and

$\mathrm{p}=$ percentage of daylight hours during the month.

The monthly consumptive-use coefficient, $k$, for various crops is given by Trelease and others (1970).

Air-temperature data (U.S. Department of Commerce, 1978) is available for the Bates Creek No. 2 station adjacent to the study area. The irrigation requirement of each crop type was computed as the difference between consumptive use and effective precipitation. The results of these computations are presented in table 4 for the three major vegetation types in the study area.

Flow measurements were made at monthly intervals on each irrigation diversion within the study area. These measurements, along with weather records and local inquiry, were used to estimate average flow rates for each month. The water in each diversion was assumed to be applied uniformly over the associated irrigated fields. Excess water applied for irrigation was computed by comparing the total applied water with irrigation requirements. The result of these computations is presented in table 5. Because no estimates were available of the percentage of excess water that enters the aquifer as recharge, the digital flow model was used to define this value. It was concluded that aquifer recharge was 80 percent of excess applied water.

\section{Evapotranspiration}

Much of the evapotranspiration within the study area is derived from water stored in the unsaturated zone and was included in the consumptive use estimates of table 4. Evapotranspiration also occurs directly from the saturated zone where the water table is close to the land surface. Evapotranspiration is assumed to occur at a maximum rate where the water table is coincident with the land surface and to decrease linearly to a depth of 10 feet. Below 10 feet virtually no evapotranspiration occurs. Rantz (1968) provides some support for this assumption when evapotranspiration occurs from grass and brush phreatophytes. While cottonwood trees occur within the Bates Creek study area, the predominate phreatophytes are properly classified as brush. A comparison of the potentiometric surface shown in figure 4 to the land-surface altitude indicates 


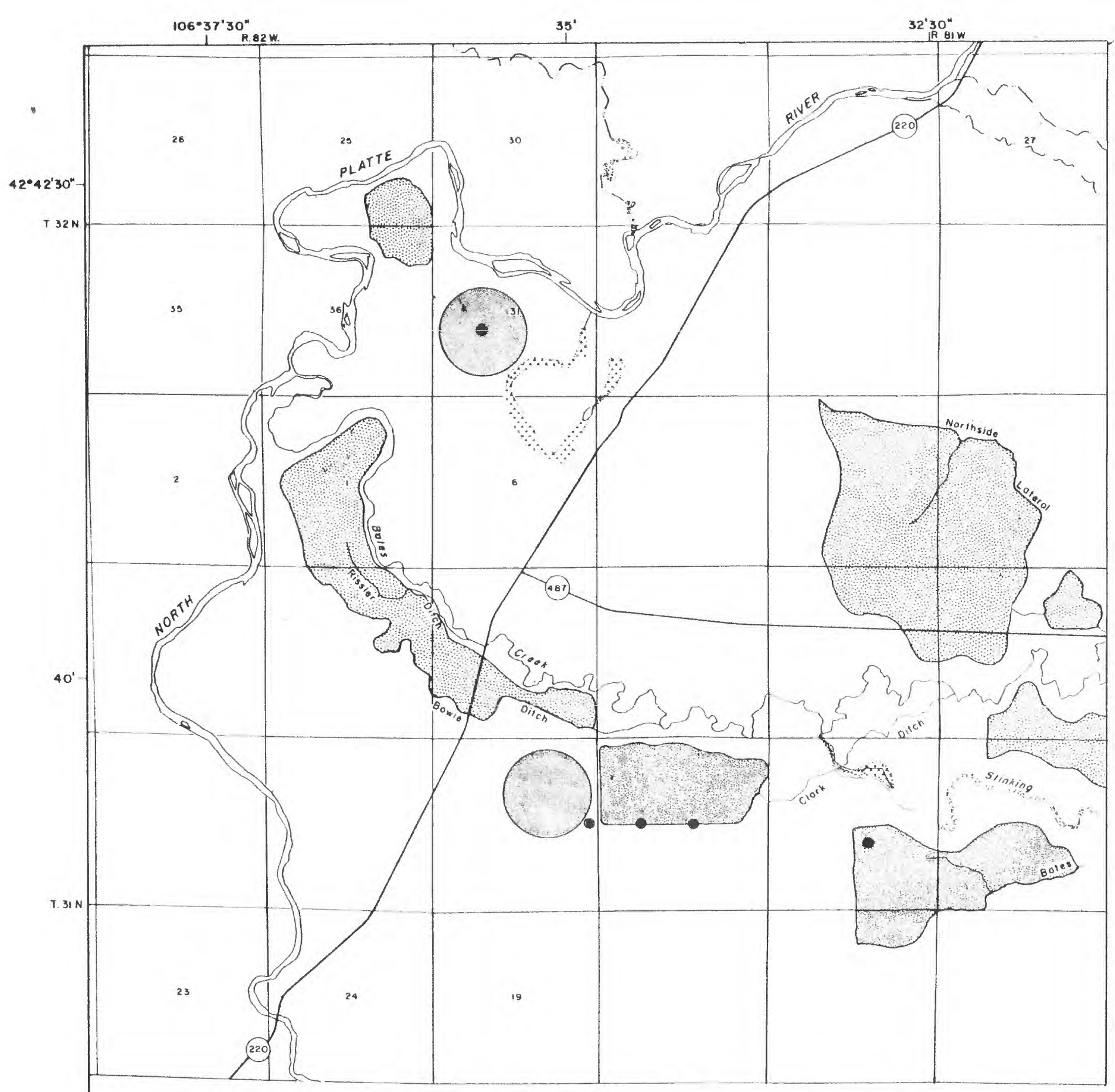

$42 \cdot 37^{\prime} 30^{\prime \prime}$

EXPLANATION

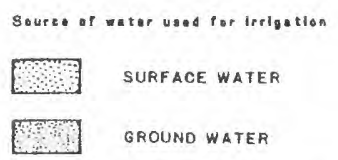

TUPOTI SURFACE WATER AND OROUND WATER

- iarigation well 


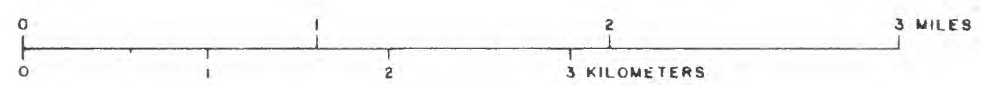

\section{U 5}

3 KILOMETERS

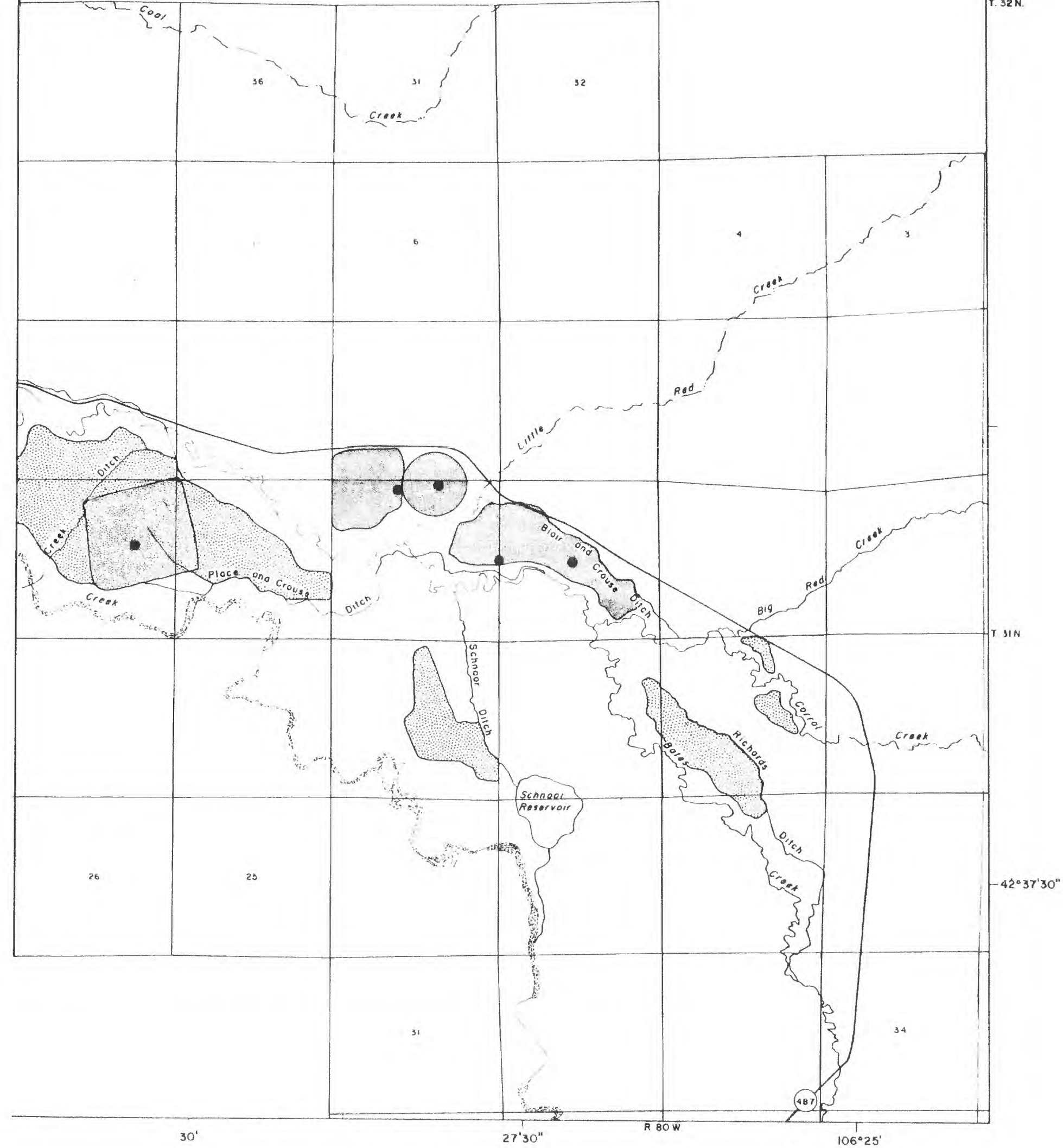




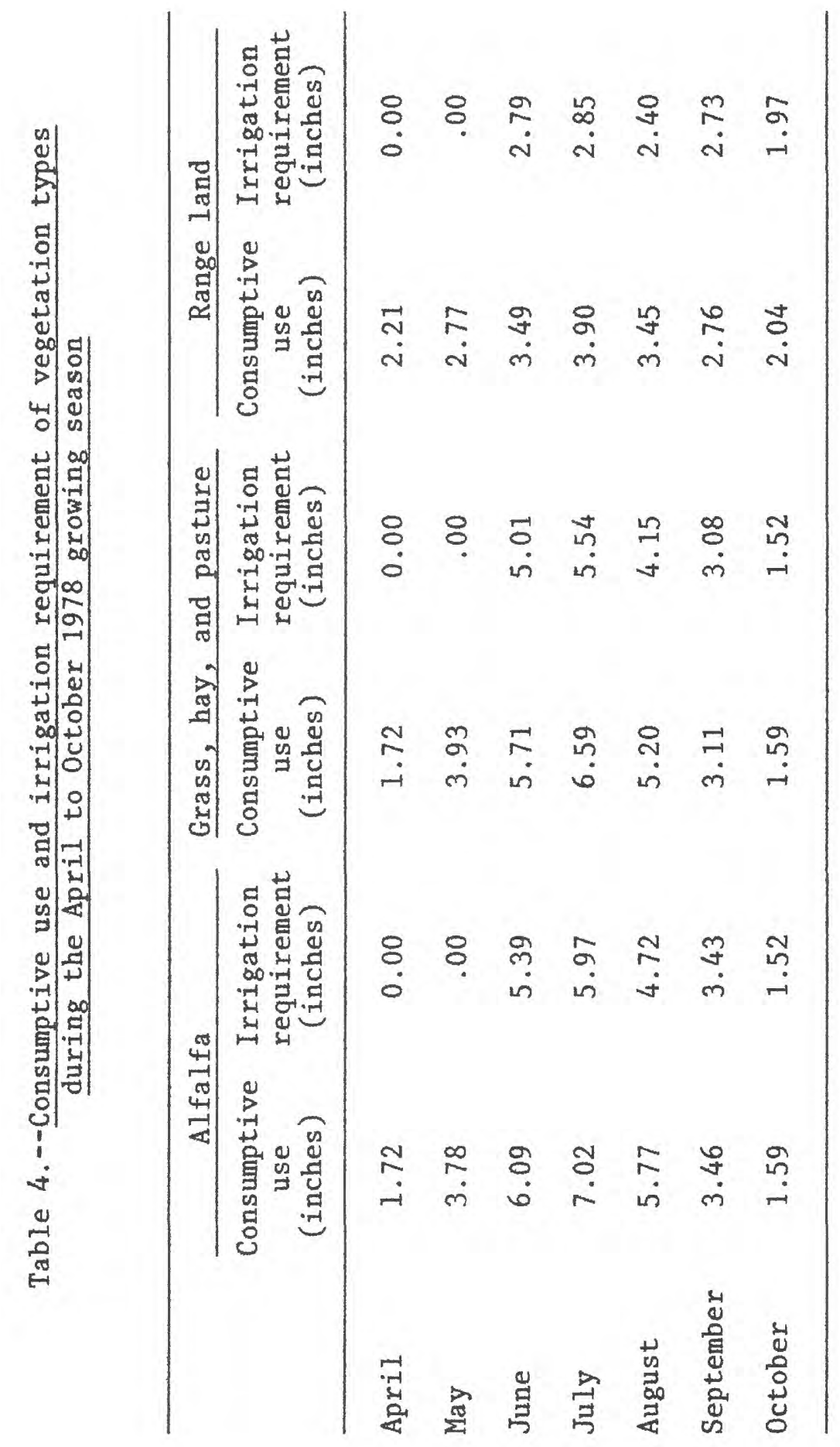


Table 5.--Excess applied water to irrigated acreage within the study area

\begin{tabular}{|c|c|c|c|c|c|c|c|}
\hline \multirow{2}{*}{$\begin{array}{l}\text { Ditch or } \\
\text { lateral }\end{array}$} & \multicolumn{7}{|c|}{$\begin{array}{l}\text { Excess applied water } \\
\text { (inches) }\end{array}$} \\
\hline & April & May & June & July & Aug. & Sept. & Oct. \\
\hline Richards & 0.0 & 0.0 & 8.9 & 8.3 & 10.8 & 8.8 & 0.0 \\
\hline Place and Crouse & 8.2 & 2.0 & .0 & .0 & .0 & .0 & .3 \\
\hline Rissler & .0 & .0 & .0 & .0 & 12.5 & 9.9 & .0 \\
\hline Bowie & .0 & .0 & 5.0 & 3.8 & .0 & .0 & 8.1 \\
\hline Clark & 13.1 & .0 & .0 & 3.3 & 4.6 & 5.8 & 4.1 \\
\hline Bates Creek & 9.5 & 4.2 & .0 & .0 & .2 & 1.8 & 1.1 \\
\hline Northside & 9.6 & 2.9 & .0 & .0 & .0 & .0 & .0 \\
\hline Schnoor & .0 & .0 & 4.4 & 4.4 & 4.4 & .0 & .0 \\
\hline
\end{tabular}


that evapotranspiration occurs primarily within the flood plains of Bates and Corral Creeks (fig. 1). Estimates of the maximum rate of evapotranspiration were made by multiplying the pan-evaporation rate measured at Pathfinder Dam (U.S. Department of Commerce, 1978) by a pan coefficient of 0.55. Pathfinder Dam is approximately 20 miles from the study area. The pan coefficient was obtained from McWhorter and Sunada (1977, p. 54). The coefficient considers the effects of relative humidity, wind, and the amount of green crop upwind from the pan. Estimates of the maximum rate of evapotranspiration from the Bates Creek aquifer during the 1978 growing season are given in table 6 .

\section{Pumpage}

Ten irrigation wells have been developed within the study area. Only seven irrigation wells were used for extended periods of time during 1978. Combined with adequate stream flows, irrigation produced little demand on the ground-water reservoir during the course of this study. Four of the wells used in 1978 were equipped with flow meters and provided direct measurements of pumpage. Power consumption (kilowatt hours of power used to pump an acre-foot of water) was determined for the remaining wells using well discharge and the power input for each well. Monthly ground-water pumpage was estimated by dividing the total power used per month by the power consumption. Total ground-water pumpage during the irrigation season was 1,030 acre-ft.

\section{SIMULATION MODEL}

A ground-water-flow model was developed to describe the Bates Creek aquifer mathematically. In addition to providing a mechanism for testing and refining hydrologic data, the model can be used to predict the future response of the aquifer to hypothetically imposed stress. A complete set of data concerning hydrologic properties and appropriate boundary conditions are required to describe flow within the aquifer in sufficient detail. To meet this requirement, the flow system was simplified to a manageable point while essential features of the system were retained.

Flow of ground water occurs in response to decreasing hydraulic head in three-dimensional space. In general, both horizontal and vertical components are present in a flow system; however, the vertical-flow component is neglected in this study. Hantush (1964) suggests that this approach is reasonable in unconfined aquifers at distances from pumping wells greater than 1.5 times the prepumping saturated thickness. This condition is met in the digital flow model because saturated thickness does not exceed $125 \mathrm{ft}$, and the minimum finite-difference-grid spacing is $750 \mathrm{ft}$. 
Table 6.--Estimated maximum rates of evapotranspiration from the Bates Creek aquifer during the April to October 1978 growing season

\begin{tabular}{lc}
\hline Month & $\begin{array}{c}\text { Evapotranspiration } \\
\text { (inches) }\end{array}$ \\
\hline April & 3.26 \\
May & 4.42 \\
June & 5.61 \\
July & 6.28 \\
August & 5.62 \\
September & 3.50 \\
October & 3.42 \\
\hline
\end{tabular}




\section{Flow Equations}

The equation of two-dimensional ground-water flow in an unconfined aquifer may be written as

$$
\frac{\partial}{\partial x}\left(K b \frac{\partial h}{\partial x}\right)+\frac{\partial}{\partial y}\left(K b \frac{\partial h}{\partial y}\right)=S_{y} \frac{\partial h}{\partial t}+W
$$

where $K=K(x, y)$ is the hydraulic conductivity, in feet per second,

$b=b(x, y, t)$ is the saturated thickness, in feet,

$h=h(x, y, t)$ is the hydraulic head, in feet,

$\mathrm{S}_{\mathrm{y}}=$ the specific yield, dimensionless,

$W=W(x, y, t)$ is the source-sink term, in feet per second,

$t=t i m e$, in seconds, and

$\mathrm{x}, \mathrm{y}=$ spatial variables, in feet.

This equation is developed under the following assumptions:

1. Vertical flow in the aquifer is negligible.

2. The variables $h$ and $K$ represent averages over the saturated thickness.

3. The aquifer is isotropic.

4. Specific yield is a constant for the whole aquifer. Although specific yield varies spatially, the variation is small enough to be neglected without seriously affecting the accuracy of the partial differential equation.

5. The source-sink term, $W$, incorporates precipitation and irrigation recharge, pumpage, and stream leakage.

Details of the derivation of equation 3 are given by Bredehoeft and Pinder (1970).

An appropriate set of boundary conditions must be provided to solve equation 3 for a particular aquifer system. A head distribution must be given at the start of the simulation along with a set of time-dependent conditions on the spatial aquifer boundaries. Spatial boundary conditions may be specified as values of head or the flow rate normal to the boundary. 


\section{Numerical Methods}

Exact solutions to the partial differential equation of ground-water flow in regional aquifer systems are rarely obtained. The complex nature of boundary conditions and hydrologic properties of most aquifers require that numerical approximations be employed. A face-centered, finitedifference approximation technique is used in the current study. This is done by placing a grid of points, called nodes, on a map of the aquifer and defining block boundries equidistant between nodes. The continuous derivations in equation 3 are then replaced by finite-difference approximations. Variable spacing between nodes is permitted. The term $\frac{\partial}{\partial x}\left(\mathrm{~Kb} \frac{\partial h}{\partial x}\right)$
is approximated at the $i$ th node by the equation

$$
\frac{(\mathrm{Kb})_{i+\frac{1}{2}}\left(\frac{\mathrm{h}_{i+1}{ }^{-h_{i}}}{\Delta \mathrm{X}_{i}}\right)-(\mathrm{Kb})_{i-\frac{1}{2}}\left(\frac{\mathrm{h}_{\mathrm{i}}-\mathrm{h}_{\mathrm{i}-1}}{\Delta \mathrm{X}_{\mathrm{i}-1}}\right)}{\frac{1}{2}\left(\Delta \mathrm{X}_{\mathrm{i}-1}+\Delta \mathrm{X}_{\mathrm{i}}\right)}
$$

where $(\mathrm{Kb})_{i+\frac{1}{2}}=$ harmonic mean of $(\mathrm{Kb})_{i}$ and $(\mathrm{Kb})_{i+1}$,

$\Delta \mathrm{x}_{i}=$ distance between nodes $i$ and $i+1$,

$(\mathrm{Kb})_{i}=$ product of hydraulic conductivity

and saturated thickness at node $i$, and

$h_{i}=$ hydraulic head at node $i$. A similar approximation is obtained for the term $\frac{\partial}{\partial y}\left(\mathrm{~Kb} \frac{\partial \mathrm{h}}{\partial \mathrm{y}}\right)$. The approxi-
mation employed for the time derivative is

$$
\mathrm{s}_{\mathrm{y}} \frac{\mathrm{h}_{\mathrm{k}}-\mathrm{h}_{\mathrm{k}-1}}{\Delta \mathrm{t}}
$$

where $S_{y}=$ specific yeild

$h_{k}=$ hydraulic head at time step $k$, and

$\Delta t=$ time increment from $k-1$ to $k$.

Application of the finite-difference approximations to equation 3 produces a set of algebraic equations that are solved iteratively for values of head at each node.

A modified version of the computer program described by Trescott and others (1976) was used in the present study. The original computer program was written for a block-centered grid with variable node spacing but has been changed by S. P. Larson (U.S. Geological Survey, written commun., 1978) to the face-centered scheme. 
The computer code also has been modified to include the streamflow accounting procedure described by Hoxie (1977). Designated stream nodes in the finite-difference grid were simulated as either gaining or losing water at rates that depend on the vertical hydraulic conductivity of the streambed and the head difference between the stream and the aquifer. Water is routed downstream while accounting for leakage, tributary inflow, and irrigation diversion. Checks were made at each stream node to insure that leakage from stream to aquifer did not exceed the calculated flow in the stream.

\section{APPLICATION OF THE SIMULATION MODEL}

Before model interpretations were accepted, the model was tested to insure that it accurately represented the real aquifer system. This was done by matching field observations of aquifer response, such as aquifer head and stream leakage, with values computed by the model. If all the hydrologic data needed to construct a flow model were known precisely, this match would be obtained directly. In the Bates Creek study this was not possible. A trial and error adjustment of hydrologic data was used to improve the match of aquifer response computed by the model with field measurements. This trial and error process is called calibration.

Water-level data collected during the 1978 water year indicated that a ground-water-flow model of the Bates Creek alluvial aquifer could be developed on the basis of three distinct time periods. Water levels remained virtually constant from December 15, 1977, to March 30, 1978. Therefore, the aquifer could be modeled during this period under steadystate conditions. Significant recharge from precipitation and surface irrigation occurred during April and May 1978. From June through October 1978 recharge from precipitation was insignificant, the distribution of surface-irrigation recharge changed, and pumpage became a source of aquifer discharge. The aquifer was modeled under transient conditions during the April and May 1978 and the June to October 1978 periods. 
Steady-State Model Development

Water-level measurements during the period December 15, 1977, to March 31, 1978, remained virtually constant. This greatly simplified the development of a digital model because the time derivative of the groundwater-flow equation could be assumed to be zero. This was incorporated in the finite-difference model by setting the specific yield to zero. The remaining hydrologic data input to the steady-state simulation was as follows:

1. Finite-Difference Grid

The face-centered finite-difference grid shown in figure 6 was designed for use in this study. A node spacing of $750 \mathrm{ft}$ was used near Bates Creek and was increased to $1,500 \mathrm{ft}$ at the north and south model boundaries. A node spacing of $750 \mathrm{ft}$ was also used in parts of T. $31 \mathrm{~N}$., R. $80 \mathrm{~W}$. where aquifer geometry is more complex. The grid was oriented to minimize computer core-storage requirements.

2. Boundary Conditions

Aquifer boundaries were modeled as having either a head that is constant with time, a flux that is constant with time, or zero flux. Boundary conditions used in the digital model are shown in figure 6. The North Platte River was modeled as a constanthead boundary because it was believed that aquifer leakage to the river was sufficient to maintain a nearly constant watertable altitude in the aquifer. Constant-flux boundaries were used near streams at the east end of the model and along the northern boundary.

3. Steady-State Potentiometric Surface

Digitized values of hydraulic head were taken directly from figure 4 by overlaying the finite-difference grid on the potentiometric-surface map.

4. Base of the Aquifer

Values were taken directly from figure 3.

5. Rate of Stream Leakage

The head difference between Bates Creek and the alluvial aquifer was assigned to insure that streams gained or lost water at the rates shown in table 2 for March 31, 1978. A streambed thickness of $1 \mathrm{ft}$ was assumed and a vertical streambed hydraulic conductivity of $2 \times 10^{-5} \mathrm{ft} / \mathrm{s}$ was obtained from field observations as described in the section on stream-aquifer relationships.

6. Parameters for the Streamflow-Accounting Procedure

Stinking Creek and all irrigation diversions were not flowing during the steady-state period. Bates Creek and Corral Creek were flowing and were included in the steady-state simulation. Data supplied to the streamflow-accounting procedure include values of stream discharge at the upstream model boundaries and designations of stream nodes. 


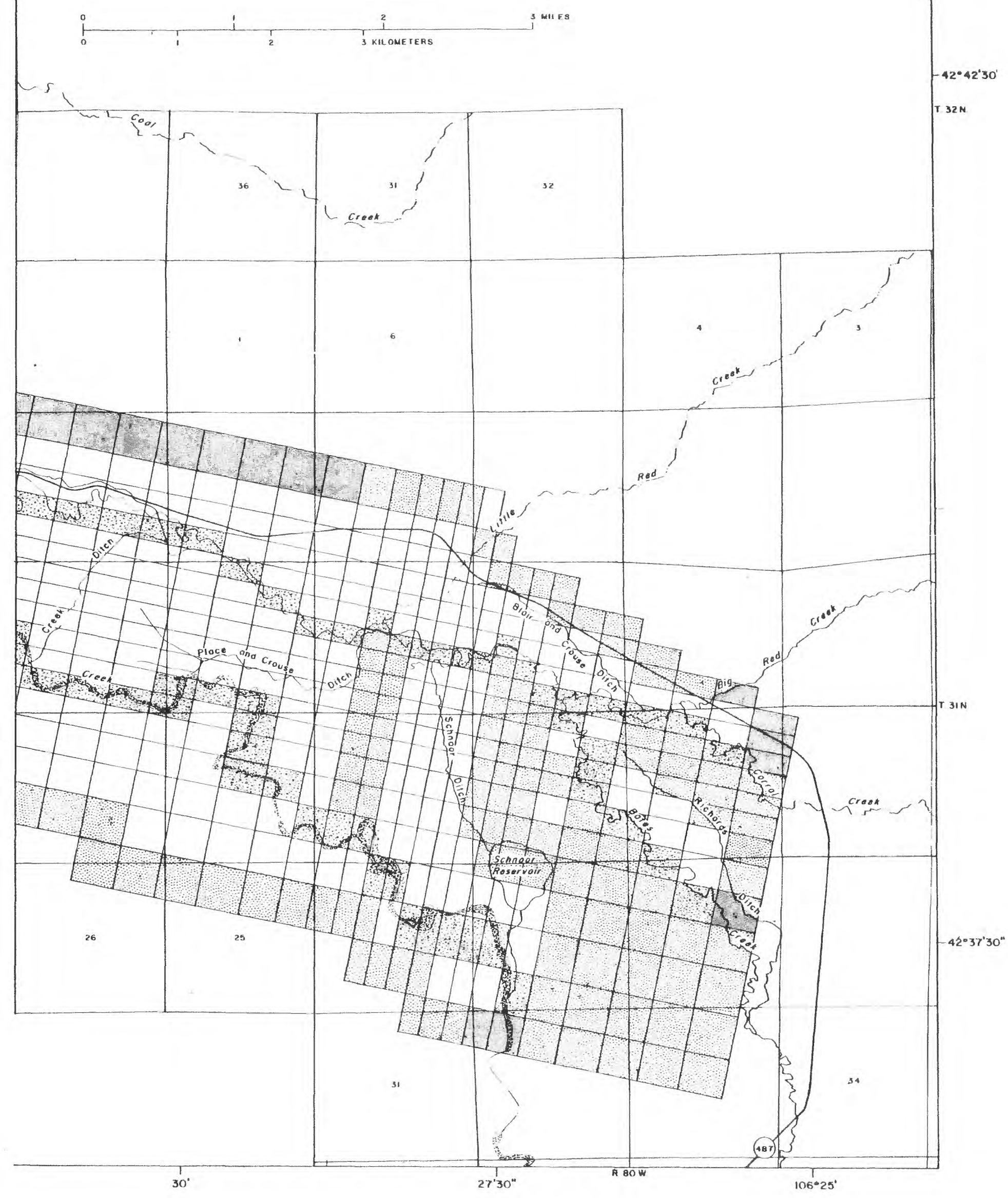


7. Rate and Distribution of Recharge by Precipitation

The criteria used to estimate steady-state recharge are described in the section on precipitation. Irrigated acreage that lies primarily north of Wyoming Highway 487 received 1.1 inches of recharge during the 75 day steady-state period. No recharge was assumed on the rest of the model area.

8. Hydraulic Conductivity

The method described in the section on hydraulic conductivity provided initial estimates of hydraulic conductivity that range from $190 \mathrm{ft} / \mathrm{d}$ to nearly $1,000 \mathrm{ft} / \mathrm{d}$.

Because all hydrologic data other than hydraulic conductivity were known in sufficient detail, the steady-state simulation was used to calculate an appropriate hydraulic-conductivity distribution. This calibration was accomplished by adjusting the distribution until an agreement between the computed head distribution and the observed potentiometric surface was judged to be satisfactory.

A measure of agreement between computed and observed head distributions is the rms (root-mean-square) deviation, defined as

$$
r m s=\left[1 / n \sum_{i=1}^{n}\left(h_{i}-h_{i}^{o}\right)^{2}\right]^{1 / 2}
$$

where $\mathrm{n}$ = number of nodes where the hydraulic head is measured,

$h_{i}=$ calculated value of head at the $i$ th node, and

$h_{i}^{\circ}=$ observed value of head at the $i$ th node.

The rms deviation is a measure of the mean departure of the calculated head distribution from the observed head distribution. It is calculated using only those nodes where water-level data were collected. If all nodes are used, the observed head distribution, obtained from figure 4, includes an interpretive bias. No attempt was made in this study to account for head differences between nodes and wells whenever the two did not coincide. Because of the relatively small node spacings, any adjustments probably would have been small.

Calibration of the steady-state model for the Bates Creek alluvial aquifer resulted in a calculated head distribution with an rms deviation of $2.4 \mathrm{ft}$. The maximum deviation between computed and observed heads was $5.7 \mathrm{ft}$. This match was judged to be satisfactory. The difference between computed and observed stream leakage along Bates Creek was 0.1 $\mathrm{ft}^{3} / \mathrm{s}$. The calibrated hydraulic-conductivity distribution was used in all subsequent transient simulations. The computed head distribution was used as an initial condition for transient simulations because it was consistent with the hydraulic conductivity and the initial recharge and discharge rates.

The estimation of aquifer properties and boundary conditions introduces uncertainties into ground-water modeling. A sensitivity analysis provides an indication of the change in computed hydraulic head resulting from a perturbation in an aquifer parameter. Such an analysis is useful in establishing tolerances within which an aquifer property may vary without significantly affecting modȩ rosults. 
Steady-state sensitivity analyses that were performed on hydraulic conductivity and precipitation recharge are summarized in table 7 . These model characteristics were chosen because they involve a large degree of uncertainty. The hydraulic-conductivity analysis was done by varying the hydraulic-conductivity distribution by constant multipliers of $0.5,1.0$, 1.5 , and 2.0 while holding all other model inputs at the calibrated values. The sensitivity analysis of precipitation recharge was made by varying the recharge distribution by constant multipliers while holding all other model data at the calibrated values. The multipliers used in these analyses were chosen because they represent the full range of uncertainty in estimates of hydraulic conductivity and recharge.

The lowest rms deviation in combination with the least number of wells that go dry occurred with a multiplier of 1.0 , the calibrated value. Deviations from the calibrated values of hydraulic conductivity caused a large number of nodes to go dry. These data do not prove that the calibration process has provided the model with the most likely set of recharge and hydraulic-conductivity data. However, the sensitivity analyses provided some evidence to support the idea that the calibration was reasonable.

\section{Transient Model Development}

The model characteristics that remained to be incorporated in the model were specific yield of the aquifer, surfacemirrigation recharge, water-table evapotranspiration, and pumpage. This was accomplished by developing the model under the transient-flow conditions of the 1978 irrigation season.

No measurement of specific yield was made during this study, but an analysis of the North Platte River alluvium by Crist (1975) indicated a value of 0.23 . Because the applicability of this value to Bates Creek alluvium was unknown, a sensitivity analysis was conducted for the period April 1 to May 22, 1978; results of which are presented in figure 7. Root-mean-square deviation of predicted change in heads from head changes observed in wells from April 1 to May 22, 1978, was used as a measure of model sensitivity. Recharge was held at 80 percent of the excess applied water, and other model inputs were held at the calibrated steady-state values.

The method described in the section on irrigation recharge yields an estimate of the magnitude and distribution of excess water applied for irrigation. This water is lost as surface runoff, ground-water recharge, and soil-moisture storage. A sensitivity analysis was conducted to determine the part of excess applied water that enters the aquifer as recharge. The period April 1 to May 22, 1978, was used in the analysis. The results are given in figure 8. Root-mean-square deviation of predicted change in heads from observed head changes from April 1 to May 1, 1978, was used as a measure of model sensitivity. The recharge distribution was varied over the entire model area using simple multipliers. Specific yield was held at 0.25 , and all other parameters were held at the steady-state calibrated values. 
Table 7.--Results of steady-state sensitivity analysis [rms, root mean square]

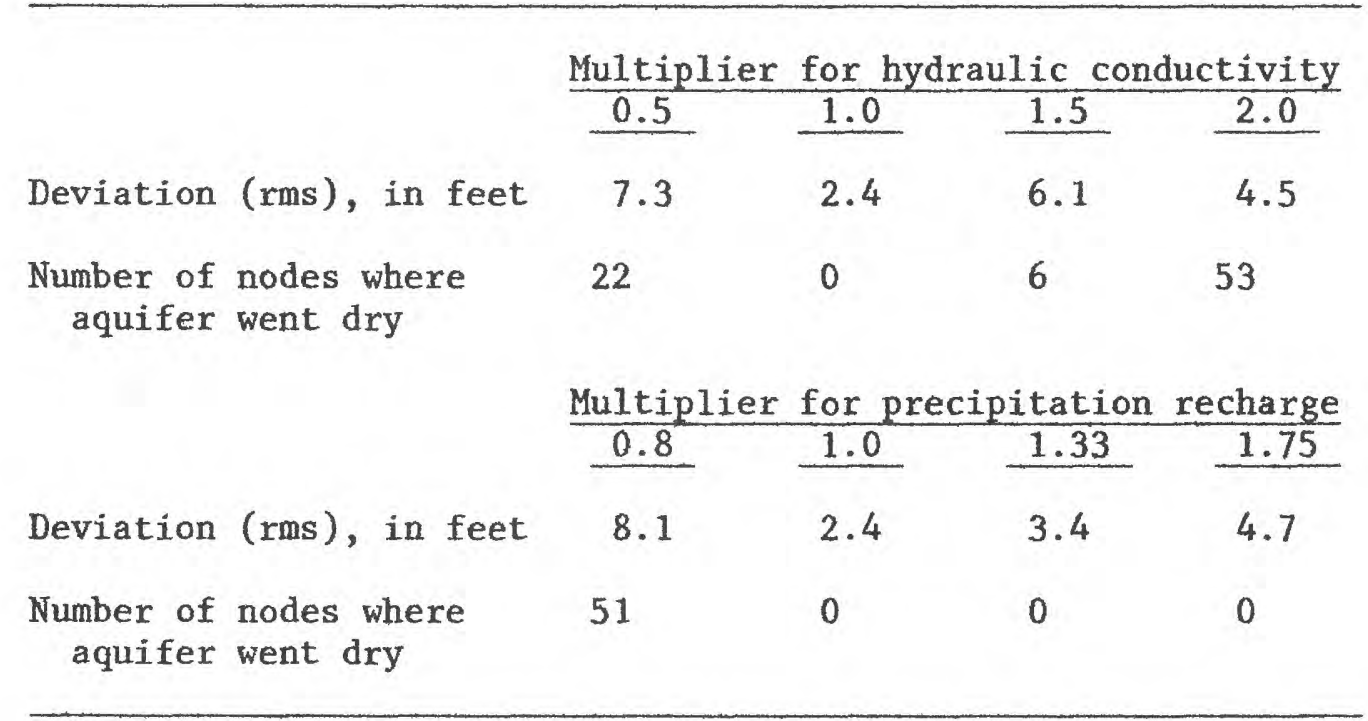




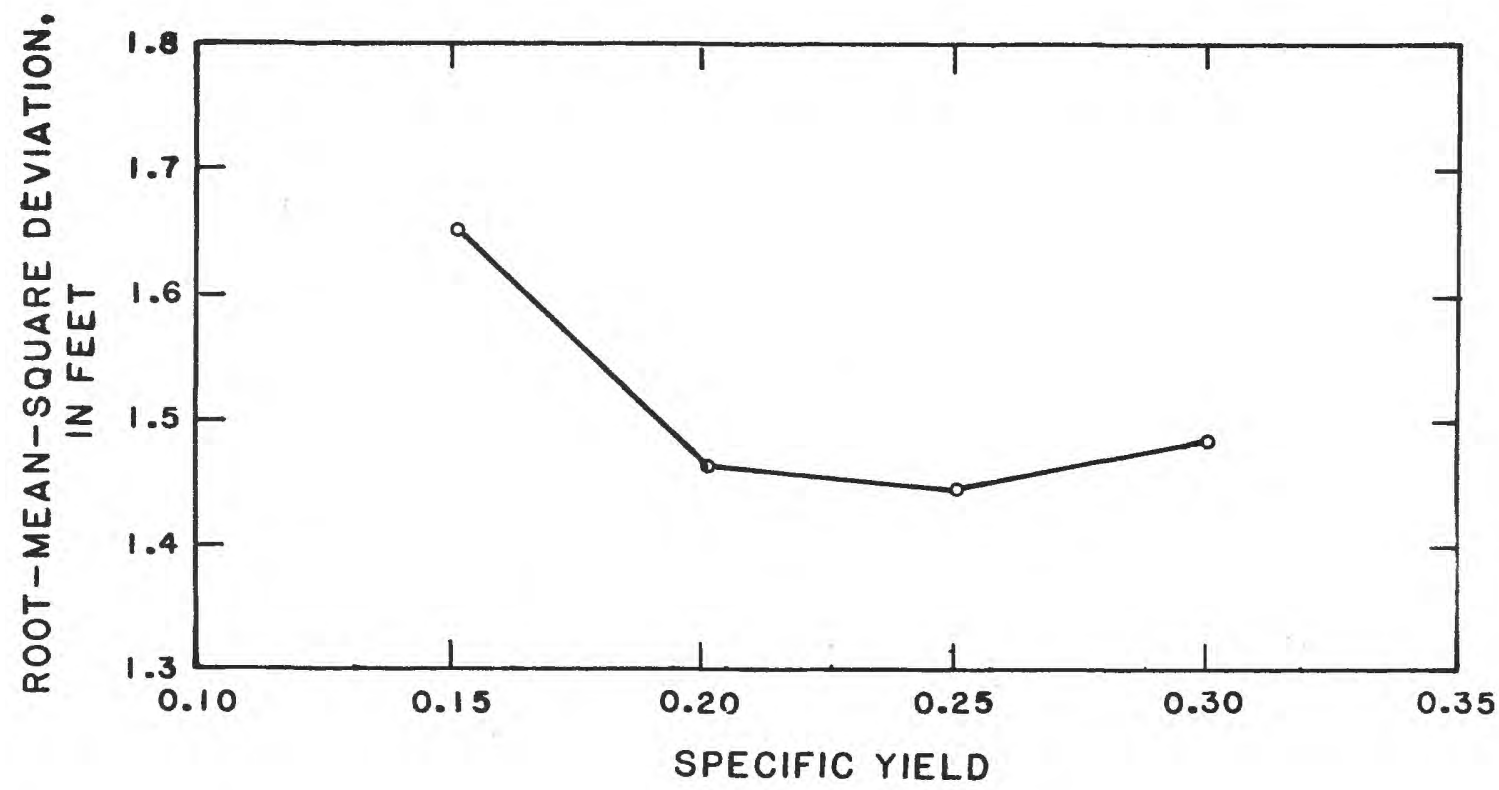

Figure 7.--Results of sensitivity analysis with different values of specific yield

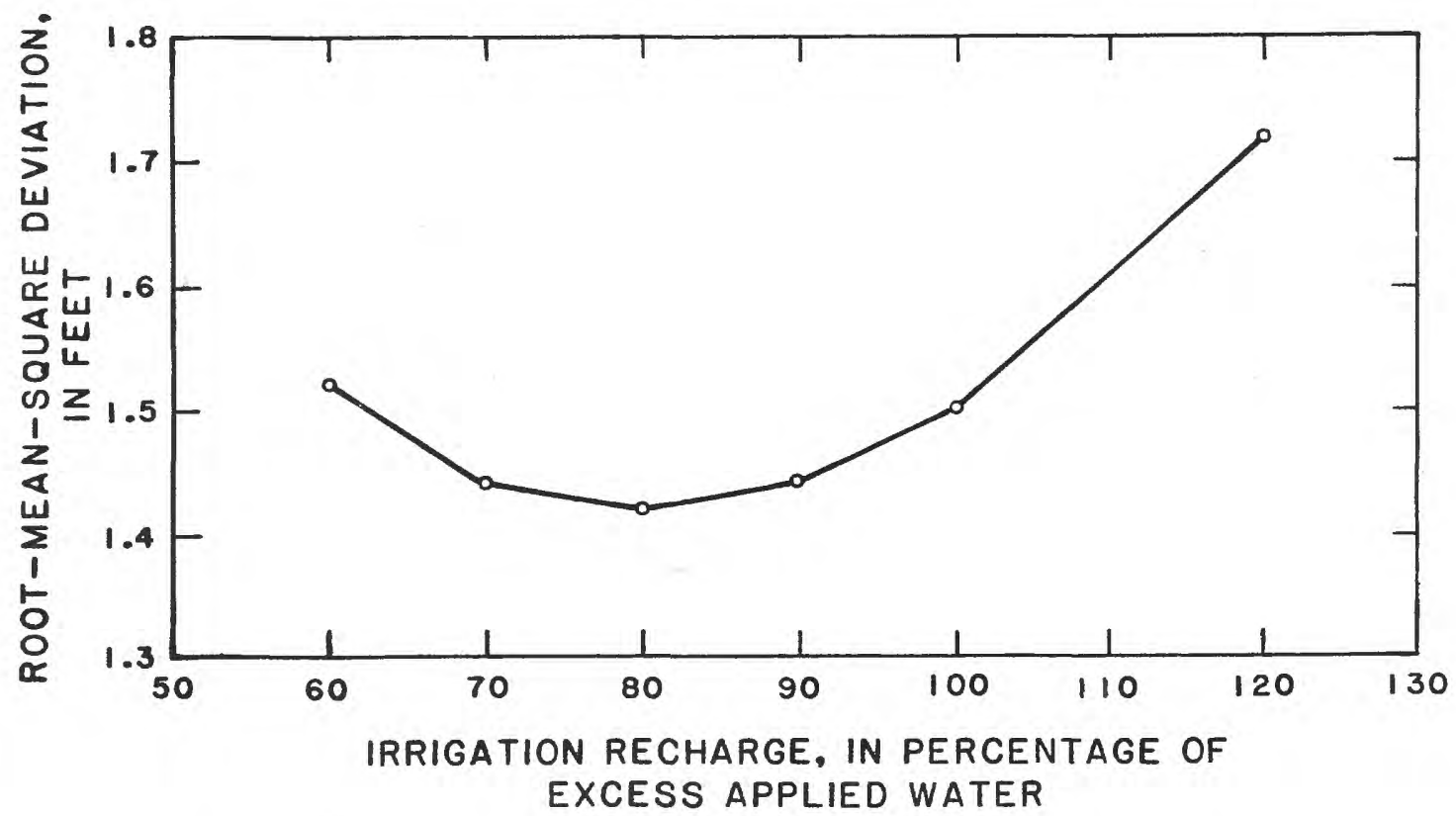

Figure 8.--Results of sensitivity analysis with different values of irrigation recharge 
The common multipliers used in the sensitivity analyses of irrigation recharge and specific yield represent the range of anticipated uncertainty in the two parameters. In figures 7 and 8 , the sensitivity graphs are not symmetric about the minimum value. In the case of figure 7 , this indicates that the model is not sensitive to uncertainty in estimates of specific yield above 0.20. From the data shown in figure 8 , it can be concluded that the model is not sensitive to uncertainty in estimates of irrigation recharge below 100 percent of excess applied water. It should be noted that recharge and specific yield are interdependent. If a higher value of recharge had been selected for the sensitivity analysis of specific yield, figure 7 would have a minimum at a lower value. Similarly, if a lower value of specific yield had been selected for the sensitivity analysis of recharge, the minimum of figure 8 would be a higher value.

Calibration of the transient model began by simulating the flow system that existed from April 1 to May 22, 1978. Water levels over the study area rose an average of $3.1 \mathrm{ft}$ during this relatively short period. The maximum change in water level was $9.6 \mathrm{ft}$. The minimum values in figures 7 and 8 were selected as initial estimates of specific yield and recharge. Some additional adjustments in the estimates were required to produce an acceptable match between simulated and observed water-level changes. The final value of recharge obtained was 80 percent of the excess applied water. A value of 0.22 was obtained for specific yield. The rms deviation of predicted changes in head from observed head changes during the period April 1 to May 22, 1978, was $1.3 \mathrm{ft}$.

The computed hydraulic-head distribution of May 22, 1978, was then used to calibrate the May 20 to October 18, 1978, simulation. Estimates of irrigation recharge for this time period were made on the basis of 80 percent of excess applied water. Values of excess applied water are given in table 5. A value of 0.22 was used for specific yield. Initial estimates of pumpage and potential evapotranspiration from the water table also were made. Actual evapotranspiration was modeled as a function of the potential rate of evapotranspiration and depth to the water table. Trial and error adjustments of a few feet in the distance between land surface and the water table were required to produce a satisfactory match between simulated and observed stream leakage.

The results of calibration during the period May 22 to October 18, 1978, are presented in table 8. The error in computed leakage for each stream reach is within the probable error of stream-discharge measurements. A 1.1-ft rms deviation of changes in water levels at 25 measured wells was judged satisfactory for this time period. 
Table 8.--Difference between calibrated and observed stream leakage on October 18, 1978 at Corral and Bates Creeks

Calibrated-observed leakage, in cubic feet per second

Corral Creek from State Highway to mouth

0.04

Bates Creek from Richards Ditch to Place .06 and Crouse Ditch

Bates Creek from Place and Crouse Ditch to $\quad-.06$ Bates Creek Ditch

Bates Creek from Bates Creek Ditch to $\quad-.12$ Clark Ditch

Bates Creek from Clark Ditch to one-half .11 mile below Stinking Creek

Bates Creek from one-half mile below $\quad-.07$ Stinking Creek to Wyoming Highway 220

Bates Creek from Wyoming Highway 220 to mouth -.10 
Three transient simulations have been made to assess the impact of existing and proposed irrigation development within the study area. Simulations were carried out for the period October 1978 through October 1988. Each calendar year was divided into a nonirrigation season from November through March and an irrigation season from April through October. No irrigation pumpage or stream diversion was assumed to occur from November through March of each year. Aquifer recharge was assumed to be negligible during the nonirrigation season. The amount of water diverted to each ditch shown in figure 2 during the irrigation season is shown in table 9. Aquifer recharge while ditches operated was estimated as 80 percent of the excess applied water.

Streamflow entering the model area also was divided into an irrigation season from April through October and a nonirrigation season. Corral Creek discharge was set equal to the mean streamflow at the U.S. Soil Conservation Service gaging station. A value of $5.2 \mathrm{ft}^{3} / \mathrm{s}$ was used during the irrigation season and $3.1 \mathrm{ft}^{3} / \mathrm{s}$ during the nonirrigation season. Bates Creek discharge was obtained by increasing the mean streamflow at the U.S. Soil Conservation Service gaging station at Steinle Ranch by 20 percent as an estimate of streamflow from ungaged tributaries between the gaging-station location and the model boundary. A value of $15.8 \mathrm{ft}^{3} / \mathrm{s}$ was used during the irrigation season and $6.0 \mathrm{ft}^{3} / \mathrm{s}$ during the nonirrigation season. No streamflow records were available for Stinking Creek, but on the basis of discussions with residents of the Bates Creek valley, values of $3.2 \mathrm{ft}^{3} / \mathrm{s}$ for the irrigation season and zero for the nonirrigation season were used for predictive simulations. Stinking Creek discharge during the irrigation season was set at a value slightly greater than the diversion rate for the Schnoor Ditch. follows:

The amount of ground-water pumpage assumed for each simulation is as

Scenario I.--Ground-water pumpage was assumed to be zero in this scenario.

Scenario II.--The irrigation wells used in this scenario (table 10) have been granted permits by the Wyoming State Engineer. Total pumpage of 1,983 acre-ft per year was estimated as the amount of water required to meet average comsumptive-use requirements of irrigated acreage.

Scenario III.- A total of 16 irrigation wells were used in this scenario. This included all wells used in scenario II and an additional seven wells that are planned for development. Total pumpage under this scenario was 3,481 acre-ft per year.

The effect of present ground-water pumping on the hydrologic system can be assessed by comparing results of scenario II and scenario I. Similarly, the effects of proposed ground-water development can be assessed by comparing results of scenario III and scenario II. 
Table 9.--Assumed irrigation diversions for simulations at 6 ditches Irrigation diversion Ditch (acre-feet per year)

Richards

Place and Crouse

Bates Creek

Clark

Schnoor

Bowie and Rissler

Total
1,530

1,060

4,500

1,490

467

$\underline{2,840}$

11,887 
Table 10.--Assumed irrigation pumping for simulation scenarios II and III

\begin{tabular}{|c|c|c|}
\hline \multirow[b]{2}{*}{ Well location } & \multicolumn{2}{|c|}{$\begin{array}{c}\text { Irrigation pumpage, in } \\
\text { acre-feet per year }\end{array}$} \\
\hline & Scenario II & Scenario III \\
\hline SW $\frac{1}{4} N W \frac{1}{4}$ sec. 7, T. 31 N., R. 80 W. & 225 & 225 \\
\hline $\mathrm{SE}_{4} \mathrm{SW}_{4}$ sec. 7, T. $31 \mathrm{~N} .$, R. $80 \mathrm{~W}$. & 245 & 245 \\
\hline $\mathrm{SE}_{4}^{\frac{3}{4}} \mathrm{NW}_{\frac{1}{4}}$ sec. 17, T. 31 N., R. 80 W. & 270 & 270 \\
\hline SW $\frac{1}{4} \mathrm{NE} \frac{1}{4} \mathrm{sec} .18$, T. $31 \mathrm{~N} .$, R. $80 \mathrm{~W}$. & 0 & 315 \\
\hline $\mathrm{NE} \frac{1}{4} \mathrm{SE} \frac{1}{4} \mathrm{sec} .18$, T. $31 \mathrm{~N} .$, R. $80 \mathrm{~W}$. & 135 & 135 \\
\hline $\mathrm{SW}_{\frac{1}{4}} \mathrm{SE}_{\frac{1}{4}} \mathrm{sec} .5$, T. $31 \mathrm{~N} .$, R. $81 \mathrm{~W}$. & 0 & 142 \\
\hline NE $\frac{1}{4}$ NW $\frac{1}{4}$ sec. 8, T. 31 N., R. 81 W. & 0 & 121 \\
\hline 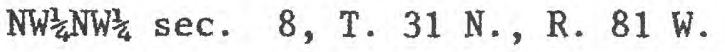 & 0 & 101 \\
\hline $\mathrm{SE}_{\frac{1}{4}} \mathrm{NE} \frac{1}{4} \mathrm{sec} .14, \mathrm{~T} .31 \mathrm{~N} ., \mathrm{R} .81 \mathrm{~W}$. & 150 & 150 \\
\hline SW $\frac{1}{4} N E \frac{1}{4}$ sec. 17, T. 31 N., R. 81 W. & 254 & 254 \\
\hline SE $\frac{1}{4} N W \frac{x}{4}$ sec. 17, T. 31 N., R. 81 W. & 254 & 254 \\
\hline 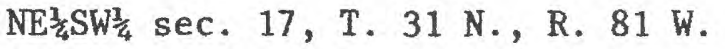 & 0 & 189 \\
\hline $\mathrm{SE}_{\frac{1}{4}} \mathrm{NE} \frac{\frac{1}{4}}{4} \mathrm{sec} .18$, T. $31 \mathrm{~N} .$, R. 81 W. & 225 & 225 \\
\hline $\mathrm{NE}_{\frac{1}{4}} \mathrm{NW}_{4}$ sec. 1, T. 31 N., R. 82 W. & 0 & 315 \\
\hline $\mathrm{SE} \frac{1}{4} \mathrm{NW} \frac{\mathrm{n}}{4}$ sec. 12, T. 31 N., R. $82 \mathrm{~W}$ & 0 & 315 \\
\hline NE $\frac{1}{4}$ SW $\frac{1}{4}$ sec. 31, T. 32 N., R. 81 W. & 225 & 225 \\
\hline Tota1, rounded & 1,980 & 3,480 \\
\hline
\end{tabular}


Water-level changes during each simulation generally are less than $15 \mathrm{ft}$. During each nonirrigation season, the potentiometric surface partly recovers from effects of pumping and irrigation recharge. Table 11 shows the effect of ground-water pumping in scenarios II and III on water levels at irrigation wells. The water-level change as a result of pumping is computed by comparing the difference between the potentiometric surface at the end of simulations II and III with the potentiometric surface at the end of simulation I. At the present rate of ground-water withdrawal, it can be concluded that yields of wells probably will not decline over the next 10 years. Development of the proposed wells simulated in scenario III should not affect yields of presently existing wells. However, water-level declines of 5 to $15 \mathrm{ft}$ are possible in the vicinity of the proposed wells.

Projected net rates of streamflow depletion along Bates and Corral Creeks as a result of assumed rates of pumping are presented in figure 9 . A sharp reduction in the rate of streamflow depletion is apparent during the nonirrigation seasons of both scenario II and scenario III. This response is indicative of a ground-water system that is dominated by hydraulic conductivity instead of by specific yield. A breakdown of projected streamflow depletion along various reaches of Bates and Corral Creeks are given in table 12 at the end of the 1983 irrigation season and in table 13 at the end of the 1988 irrigation season. Streamflow depletion as a result of pumping in scenarios II or III is computed as the difference between the rates of stream leakage for the respective scenario and scenario I. Streamflow at all headgates was adequate to permit the diversion rates given in table 9 because average values of stream inflow to the model area were used throughout each 10-year simulation. If sufficient streamflow-gaging records had been available, a method based on streamflow statistics could have been developed to vary stream discharge from year to year. It is likely that Bates Creek would have been predicted not to flow during some periods of each simulation.

The major change in the rate of streamflow depletion occurs during the first two years of each simulation. By the fifth year of scenario II, streamflow depletion has obtained a nearly constant value of 3.4 $\mathrm{ft}^{3} / \mathrm{s}$. Streamflow depletion as a result of pumping in scenario III increases throughout the 10-year simulation. Under the second scenario, where only existing wells are used, streamflow depletion after 10 years is 69 percent of total ground-water pumpage. Streamflow depletion at the end of the third simulation, with all existing and proposed wells used, is projected to be 61 percent of total pumpage. This lower percentage, when compared to the second scenario, can be attributed to the greater distance between proposed wells and Bates Creek than exists with present wells.

The prediction of aquifer response to a set of long-term stresses is the final test of a ground-water-flow model. Adequate data are not available in the Bates Creek area to perform this test. The information could be obtained by collecting pumping, water-level, and streamflow data as ground-water development continues. The additional data could be used to verify the accuracy of the model in predicting drawdowns and streamaquifer relations. Until this is done, the reliability of predictions made by the model cannot be determined. The three scenarios described in this report represent conditions that vary only slightly from precipitation, streamflow, and pumping conditions that existed during model 
Table 11.--Predicted water-level decline at wells as a result of pumping after 10-year simulations

\begin{tabular}{|c|c|c|}
\hline \multirow[b]{2}{*}{ Well location } & \multicolumn{2}{|c|}{$\begin{array}{c}\text { Water-level decline } \\
\text { (feet) }\end{array}$} \\
\hline & Scenario II & Scenario III \\
\hline SW $\frac{2}{4} N W \frac{1}{4}$ sec. 7, T. 31 N., R. 80 W. & 1.9 & 2.5 \\
\hline SE $\frac{1}{4} S W \frac{2}{4}$ sec. 7, T. 31 N., R. 80 W. & 1.6 & 2.1 \\
\hline SE $\frac{1}{4} N W \frac{1}{4}$ sec. 17, T. 31 N., R. 80 W. & 1.4 & 1.5 \\
\hline SW $\frac{1}{4} N_{\frac{1}{4}}^{\frac{1}{4}} \mathrm{sec} .18$, T. $31 \mathrm{~N},$, R. 80 W. & 1.2 & 2.1 \\
\hline $\mathrm{NE}_{\frac{1}{4}} \mathrm{SE}_{\frac{1}{4}} \mathrm{sec} .18, \mathrm{~T} .31 \mathrm{~N} .$, R. $80 \mathrm{~W}$ & 1.1 & 1.5 \\
\hline SW $\frac{1}{4} S E \frac{1}{4}$ sec. 5, T. 31 N., R. 81 W. & .0 & 5.8 \\
\hline $\mathrm{NE}_{\frac{1}{4}} \mathrm{NW} \frac{1}{4} \mathrm{sec} .8, \mathrm{~T} .31 \mathrm{~N} ., \mathrm{R} .81$ W. & .0 & 7.3 \\
\hline NW/ $N_{4}^{\frac{1}{4}}$ sec. 8, T. 31 N., R. 81 W. & .0 & 7.4 \\
\hline SE $\frac{1}{4} \mathrm{NE} \frac{1}{4} \mathrm{sec} .14$, T. 31 N., R. 81 W. & .8 & .8 \\
\hline SW $\frac{1}{4} N E \frac{1}{4}$ sec. 17, T. 31 N., R. 81 W. & 2.6 & 3.0 \\
\hline $\mathrm{SE}_{\frac{1}{4}} \mathrm{NW} \frac{1}{4} \mathrm{sec} .17$, T. $31 \mathrm{~N} .$, R. 81 W. & 2.9 & 3.5 \\
\hline $\mathrm{NE} \frac{1}{4} \mathrm{SW}_{\frac{1}{4}} \mathrm{sec} .17, \mathrm{~T} .31 \mathrm{~N} .$, R. 81 W. & 2.0 & 6.9 \\
\hline $\mathrm{SE} \frac{1}{4} \mathrm{NE} \frac{1}{4} \mathrm{sec} .18$, T. $31 \mathrm{~N} .$, R. $81 \mathrm{~W}$. & 2.6 & 3.2 \\
\hline 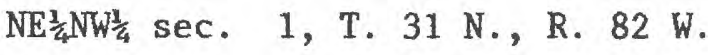 & .0 & 12.0 \\
\hline SE $\frac{1}{4} N W \frac{1}{4}$ sec. 12, T. 31 N., R. 82 W. & .1 & 9.7 \\
\hline NE $\frac{1}{4}$ SW $\frac{2}{4}$ sec. 31, T. 32 N., R. 81 W. & 3.1 & 3.7 \\
\hline
\end{tabular}




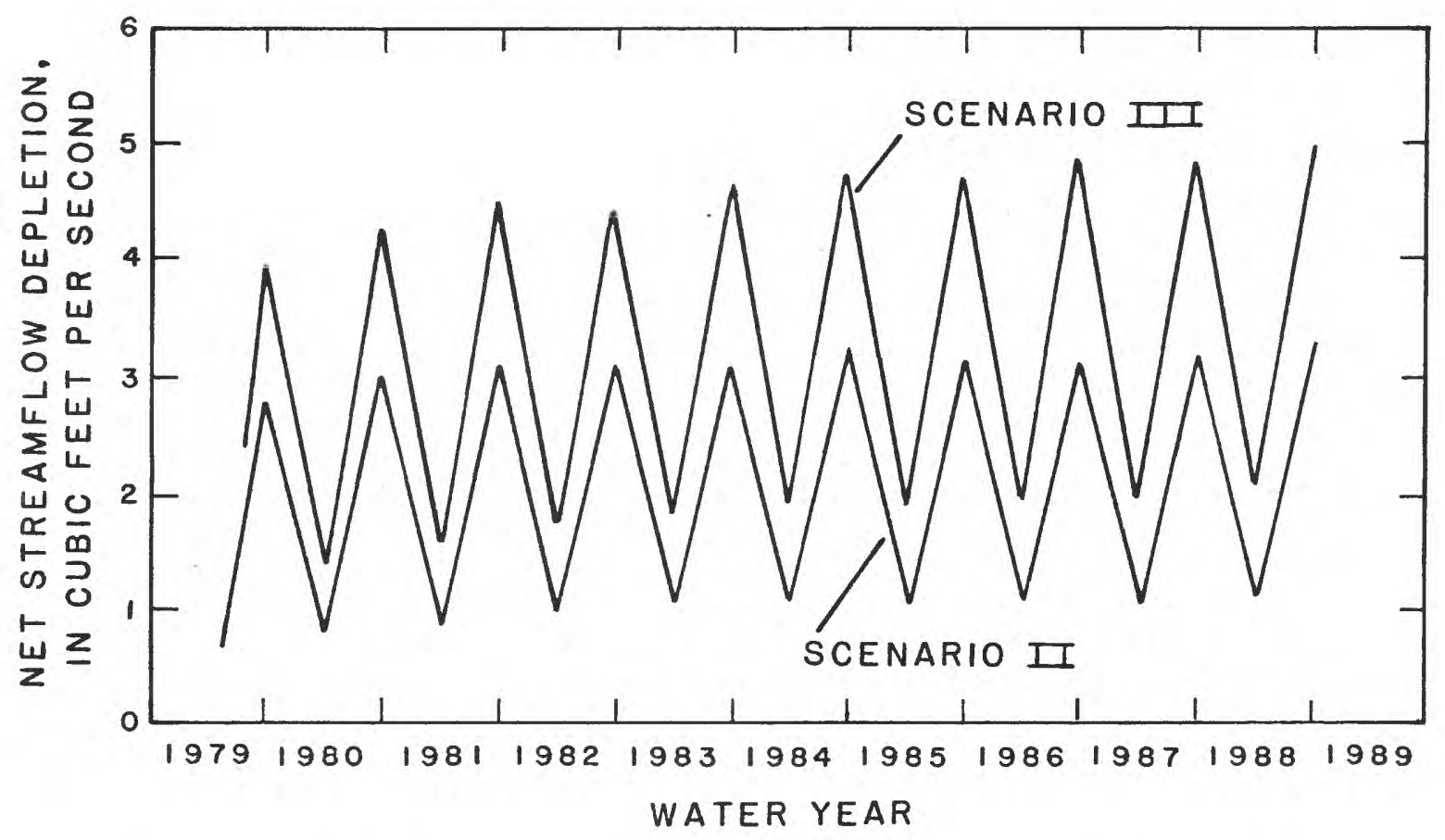

Figure 9.--Projected net streamflow depletion. 


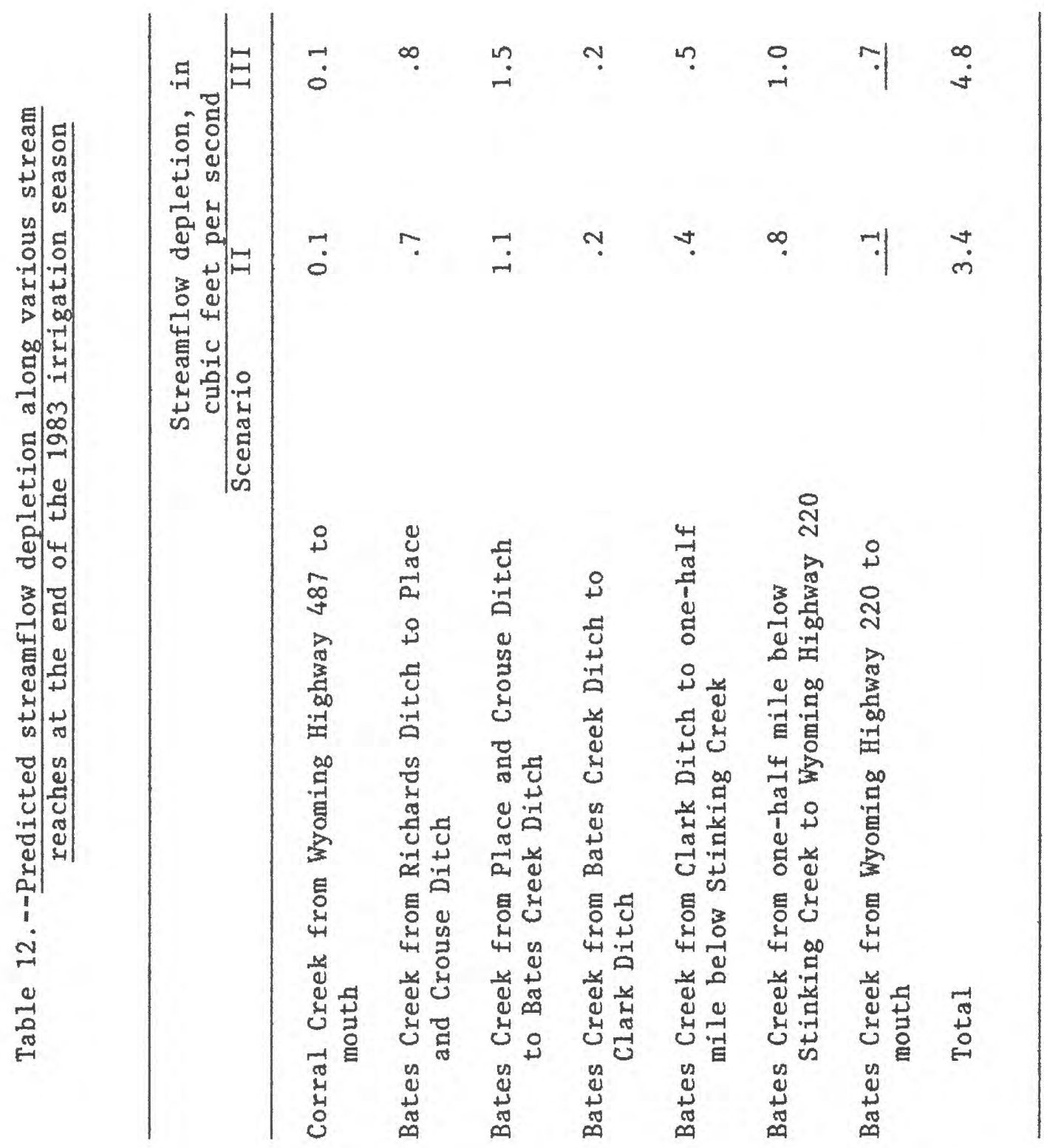


Table 13.--Predicted streamflow depletion along various stream reaches at the end of the 1988 irrigation season

\begin{tabular}{|c|c|c|c|}
\hline & \multicolumn{3}{|c|}{$\begin{array}{l}\text { Streamflow depletion, in } \\
\text { cubic feet per second }\end{array}$} \\
\hline & Scenario & II & III \\
\hline $\begin{array}{l}\text { Corral Creek from Wyoming Highway } 487 \text { to } \\
\text { mouth }\end{array}$ & & 0.1 & 0.1 \\
\hline $\begin{array}{l}\text { Bates Creek from Richards Ditch to Place } \\
\text { and Crouse Ditch }\end{array}$ & & .7 & .8 \\
\hline $\begin{array}{c}\text { Bates Creek from Place and Crouse Ditch } \\
\text { to Bates Creek Ditch }\end{array}$ & & 1.3 & 1.7 \\
\hline $\begin{array}{l}\text { Bates Creek from Bates Creek Ditch to } \\
\text { Clark Ditch }\end{array}$ & & .2 & .3 \\
\hline $\begin{array}{l}\text { Bates Creek from Clark Ditch to one-half } \\
\text { mile below Stinking Creek }\end{array}$ & & .3 & .5 \\
\hline $\begin{array}{l}\text { Bates Creek from one-half mile below } \\
\text { Stinking Creek to Wyoming Highway } 220\end{array}$ & & .8 & 1.0 \\
\hline $\begin{array}{l}\text { Bates Creek from Wyoming Highway } 220 \text { to } \\
\text { mouth }\end{array}$ & & $\stackrel{.1}{-}$ & .5 \\
\hline Total & & 3.5 & 4.9 \\
\hline
\end{tabular}


development. No quantitative measures of the accuracy of the simulation results were made, but model projections were judged to be reasonable indicators of stream-aquifer relations.

The limiting factor in using the results of the predictive simulations given in this report is believed to be the uncertainty in stream inflow rates and diversion rates. Because average values of these input parameters were used in the 10-year simulations, the magnitude and timing of actual ground-water discharge through 1988 may differ from predicted discharge rates. This is particularly likely to occur if stream discharge entering the model area is insufficient to prevent Bates Creek from flowing in its middle and lower reaches.

\section{SUMMARY AND CONCLUSIONS}

The Bates Creek aquifer southwest of Casper, Wyo., was simulated by a digital flow model. The aquifer consists of alluvial and windblown material with a saturated thickness that ranges from 0 to more than 80 ft. Cretaceous shale forms an impermeable base to the aquifer. Major sources of aquifer recharge included underflow, infiltration from precipitation and surface irrigation, and stream leakage along Corral and Stinking Creeks. Major areas of aquifer discharge were streamflow gains along the North Platte River and Bates Creek, ground-water pumping, and evapotranspiration from stream flood plains.

The ground-water-flow model was based on hydrologic data collected during the 1978 water year. The digital flow model was developed under steady-state conditions that existed during March 1978 and was used to generate a hydraulic-conductivity distribution. Development of the model with the transient-flow conditions of April through October 1978 refined estimates of specific yield, evapotranspiration, and the distribution of recharge from surface irrigation.

Three scenarios for operation of the stream-aquifer system were evaluated with the digital model. The scenarios represent no groundwater pumping, pumping, by existing wells and pumping by existing and proposed wells. Water level changes as a result of pumping are projected to decrease less than $15 \mathrm{ft}$ by the year 1988. Streamflow depletion along Bates and Corral Creeks as a result of ground-water development is projected to vary between scenarios. Under a scenario where existing wells are used, ground-water discharge to Bates Creek is predicated to decrease by $3.5 \mathrm{ft}^{3} / \mathrm{s}$ after 10 years. Pumping by all existing wells and 7 proposed irrigation wells is predicted to cause a streamflow depletion of $4.9 \mathrm{ft}^{3} / \mathrm{s}$ after 10 years.

The results of the predictive simulations are believed to be reasonable indicators of stream-aquifer relationships in the Bates Creek valley through 1988. The primary limitation in using these predictions seems to be related to uncertainty in stream discharge into the model area, ground-water pumpage rates and water-use data. Because average values of these input parameters were used in the predictive simulations, the magnitude and timing of actual ground-water discharge to Bates Creek may differ from predicted results. This is particularly likely to occur if stream discharge entering the model area is insufficient to prevent Bates Creek from flowing in its middle and lower reaches. 
Bredehoeft, J. D., and Pinder, G. F., 1970, Digital analysis of areal flow in multiaquifer ground-water systems: A quasi threedimensional model: Water Resources Research, v. 6, no. 3, p. $883-888$.

Crist, M. A., 1974, Selenium in waters in and adjacent to the Kendrick Project, Natrona County, Wyoming: U.S. Geological Survey WaterSupply Paper 2023, 39 p.

1975, Hydrologic analysis of the valley-fill aquifer North Platte River valley, Goshen County, Wyoming: U.S. Geological Survey WaterResources Investigations $75-3,60 \mathrm{p}$.

Crist, M. A., and Lowry, M. E., 1972, Ground-water resources of Natrona County, Wyoming: U.S. Geological Survey Water-Supply Paper 1897, $92 \mathrm{p}$.

Hantush, M. S., 1964, Hydraulics of wells, in Chow, Ven te, ed., Advances in Hydroscience, v. 1: New York, Academic Press, p. 281-442.

Hoxie, D. T., 1977, Digital model of the Arikaree aquifer near Wheatland, southeastern Wyoming: U.S. Geological Survey Open-File Report $77-676,54 \mathrm{p}$.

Lappala, E. G., 1978, Quantitative hydrogeology of the Upper Republican Natural Resources District, southwest Nebraska: U.S. Geological Survey Water-Resources Investigations 78-38, 200 p.

Lohman, S. W., 1979, Ground-water hydraulics: U.S. Geological Survey Professional Paper 708, 70 p.

McWhorter, D. B., and Sunada, D. K., 1977, Ground-water hydrology and hydraulics: Fort Collins, Colo., Water Resources Publications, p. 54 .

Moore, J. E., and Jenkins, C. T., 1966, An evaluation of the effect of ground-water pumpage on the infiltration rate of a semipervious streambed: Water Resources Research, v. 2, no. 4, p. 671-696.

Rantz, S. E., 1968, A suggested method for estimating evapotranspiration by native phreatophytes: U.S. Geological Survey Professional Paper 600-D, p. D10-D12.

Trelease, F. J., Swartz, T. J., Rechard, P. A., and Burman, R. D., 1970, Consumptive use of irrigation water in Wyoming: Wyoming Water Planning Report 5, Wyoming State Engineer's office, 83 p.

Trescott, P. C., Pinder, G. F., and Larson, S. P., 1976, Finitedifference model for aquifer simulation in two dimensions with results of numerical experiments: U.S. Geological Survey Techniques of Water-Resources Investigations, Book 7, Chapter C2, $116 \mathrm{p}$.

U.S. Department of Commerce, 1978, Climatological Data; Environmental Science Services Administration: Washington, U.S. Government Printing Office. 